\title{
Novel Trends in Lyotropic Liquid Crystals
}

\author{
Ingo Dierking $1, * \mathbb{C}$ and Antônio Martins Figueiredo Neto $2, * \mathbb{C}$ \\ 1 Department of Physics and Astronomy, University of Manchester, Oxford Road, Manchester M139PL, UK \\ 2 Complex Fluids Group, Institute of Physics, University of São Paulo, Rua do Matão, 1371 Butantã, \\ São Paulo-SP-Brazil CEP 05508-090, Brazil \\ * Correspondence: ingo.dierking@manchester.ac.uk (I.D.); afigueiredo@if.usp.br (A.M.F.N.); \\ Tel.: +44-161-275-4067 (I.D.); +55-11-30916830 (A.M.F.N.)
}

Received: 25 June 2020; Accepted: 10 July 2020; Published: 12 July 2020

\begin{abstract}
We introduce and shortly summarize a variety of more recent aspects of lyotropic liquid crystals (LLCs), which have drawn the attention of the liquid crystal and soft matter community and have recently led to an increasing number of groups studying this fascinating class of materials, alongside their normal activities in thermotopic LCs. The diversity of topics ranges from amphiphilic to inorganic liquid crystals, clays and biological liquid crystals, such as viruses, cellulose or DNA, to strongly anisotropic materials such as nanotubes, nanowires or graphene oxide dispersed in isotropic solvents. We conclude our admittedly somewhat subjective overview with materials exhibiting some fascinating properties, such as chromonics, ferroelectric lyotropics and active liquid crystals and living lyotropics, before we point out some possible and emerging applications of a class of materials that has long been standing in the shadow of the well-known applications of thermotropic liquid crystals, namely displays and electro-optic devices.
\end{abstract}

Keywords: liquid crystal; lyotropic; chromonic; amphiphilic; colloidal; application

\section{Introduction}

Lyotropic liquid crystals (LLCs) [1,2] are known from before the time of the discovery of thermotropics by Reinitzer in 1888 [3], which is generally (and rightly) taken as the birth date of liquid crystal research. In the work before this time, for example by Virchow [4], Mettenheimer [5], Planer [6], Loebisch [7] or Rayman [8], the liquid crystalline properties were described, but without the explicit realization that this constituted a novel state of matter. The latter was the significant contribution made by Reinitzer [3] in 1888 and Lehmann [9], who coined the term "liquid crystal" in 1889 when studying thermotropic phases. Nevertheless, lyotropic liquid crystal research has been present ever since, albeit on a lower quantitative output than that of thermotropic systems, also because of their less obvious potential in applications, being overshadowed by displays and electro-optic devices. But, as thermotropic liquid crystal research surged in the 1970's to the 2000's, so did that of lyotropic liquid crystals (Figure 1), due to the realization of their importance for biological systems and in colloid science.

Over the last two decades, more and more LC researchers have widened the scope of their work to also include lyotropic phases, and to explore systems of both thermotropic and lyotropic behavior. This paper will try and summarize some of the fascinating recent developments, as lyotropics find their way into an increasing number of liquid crystal laboratories. This will by no means be an exhaustive treatment, but will hopefully provide an overview of the current new trends in lyotropic liquid crystals. 


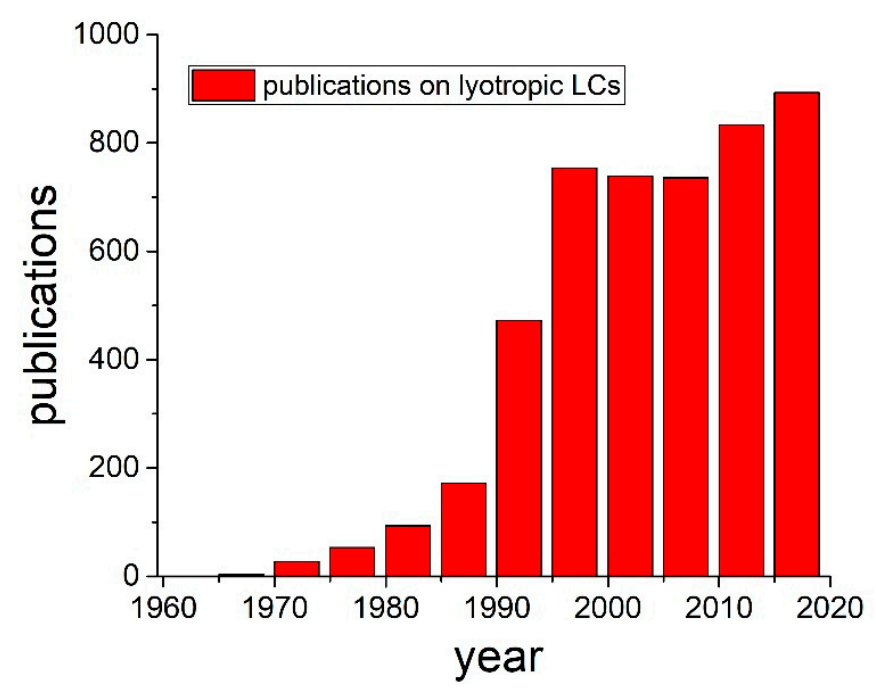

Figure 1. Number of publications in the field of lyotropic liquid crystals (LLCs) shown as bars over a time period of 5 years each.

\section{Lyotropic Liquid Crystals}

\subsection{Classic Lyotropics from Amphiphiles and Polymers}

Amphiphilic molecules have the striking property of presenting two antagonistic characteristics within the same molecule, i.e., hydrophobicity and hydrophilicity. In contact with polar and/or nonpolar liquids, under proper temperature and relative concentration conditions, they form lyotropic liquid crystalline phases [1]. Nanoscale molecular segregation (self-assembly) gives rise to different molecular aggregates, from micelles to bicontinuous structures. There are different types of amphiphilic molecules, such as anionic, cationic, zwitterionic and non-ionic amphiphiles, detergents and anelydes [10]. Moreover, other more complex molecules belong to this category, the gemini surfactants [11], the rigid spiro-tensides, phospholipids [12], the facial amphiphiles [13] and the bolaamphiphiles [14]. The lyotropic polymorphism encountered in mixtures with amphiphilic molecules is very rich. Figure 2 shows a sketch of a typical lyotropic liquid crystal phase diagram of a mixture composed by an amphiphile and water. The Krafft line separates the crystalline phase region from the liquid region. The critical micelle concentration line separates the single amphiphilic molecule region from the molecular self-assembled region. By increasing the amphiphile relative concentration, the mixture can present the micellar, hexagonal, lamellar and inverted phase structures. A well-known biological example for lyotropic lamellar structures is the lipid bilayers of cell membranes, as shown in Figure 3a. Other examples are Myelin figures. 


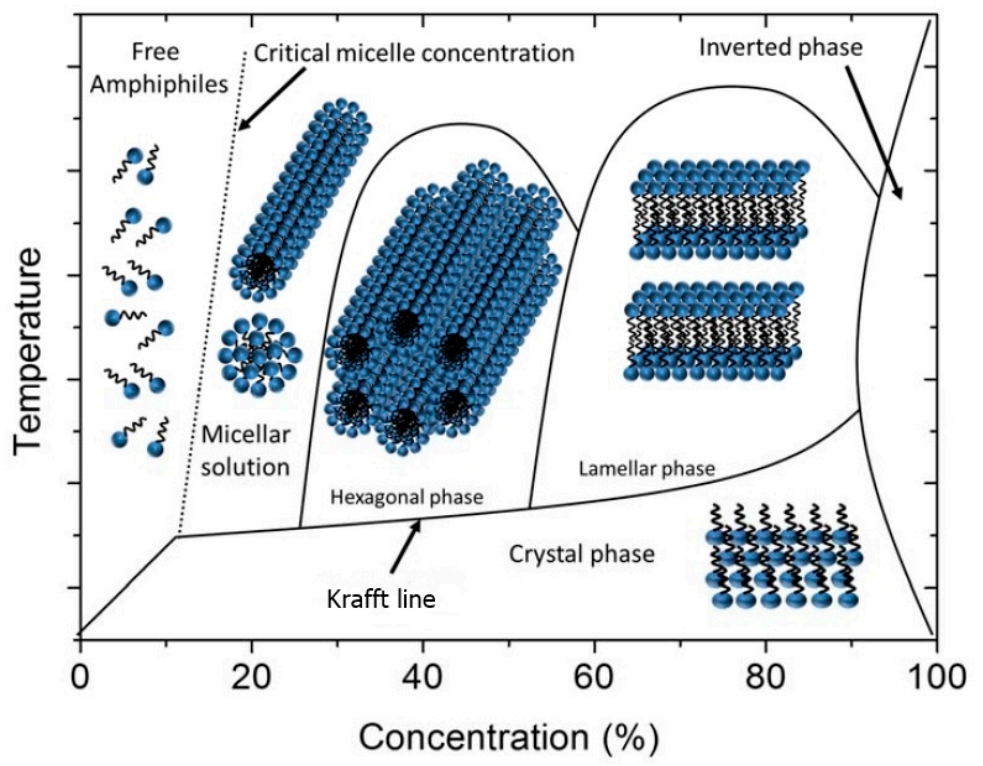

Figure 2. Sketch of a phase diagram of a mixture of an amphiphile and water. In the horizontal axis, the amphiphile concentration is represented. Cubic phases may occur at different areas in the phase diagram.

(a)

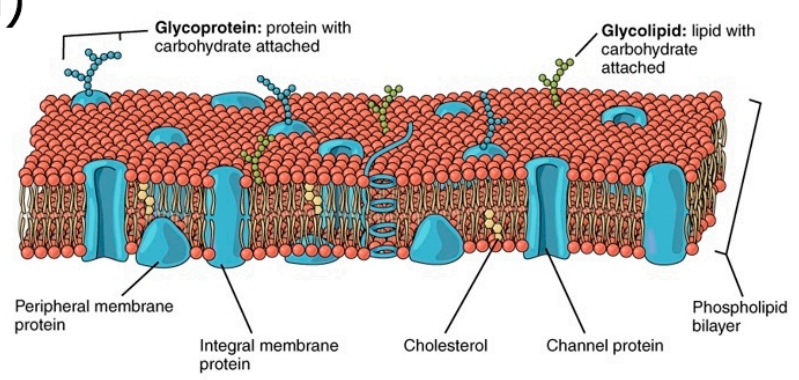

(b)

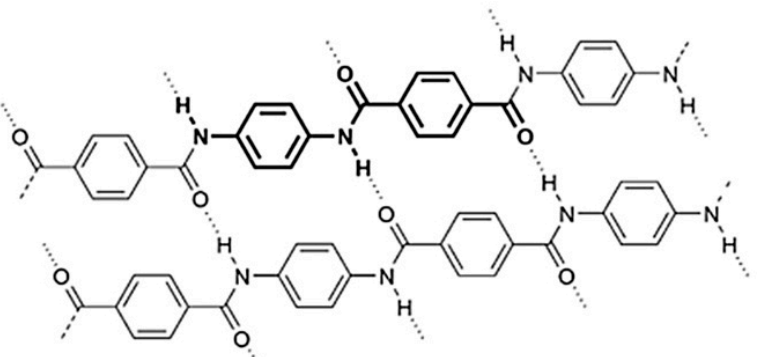

Figure 3. (a) Schematic representation of the lyotropic liquid crystalline structure of a cell membrane (reproduced from Wikimedia Commons from OpenStax Anatomy and Physiology). (b) Chemical structure of Kevlar ${ }^{\circledR}$.

Despite the fact that these liquid crystalline phases were extensively studied for many decades, interesting questions still remain to be answered nowadays. Two of these mesophases deserve to be particularly highlighted, the biaxial nematic, $\mathrm{N}_{\mathrm{B}}[15,16]$, and the chiral $[17,18]$ mesophases.

Controversies have appeared in the literature over the years about the existence of the $\mathrm{N}_{B}$ phase and its chemical stability. Theoretical $[16,19]$ and experimental $[16,20,21]$ papers were published about the stability of the $\mathrm{N}_{\mathrm{B}}$ phase. In this special issue, an extensive discussion about the experimental conditions to stabilize the $\mathrm{N}_{\mathrm{B}}$ phase is presented. 
Chiral lyotropics is, still, a challenge to be fully understood by physicists and chemists. An intriguing question is how the information about chirality passes from one element of the structure (micelle or lamellae) to the next, since there are water molecules between them. Recently, evidences of an equivalent to the thermotropic (chiral smectic C), $\mathrm{SmC}^{*}$, in lyotropics were reported [18]. These findings further broaden the boundaries of the physical chemistry of lyotropic liquid crystals.

Another class of lyotropic liquid crystals involve polymers in an isotropic, liquid solvent. One classic example found in nature is spider silk, which consists of protein fibers formed from a micellar solution when pushed through a valve at the spiders back under loss of water. This forms oriented crystalline regions of beta-sheets cross-linked via amorphous regions. Another industrially produced high modulus fiber is Kevlar ${ }^{\circledR}$ (Figure 3b), which is produced from the lyotropic liquid crystalline state of the aramide polymer in highly concentrated sulfuric acid. It is used in a wide range of applications, from bullet proof vests to climbing gear.

\subsection{Inorganic Liquid Crystals}

The most classic example of an inorganic or mineral liquid crystal is vanadium pentoxide, $\mathrm{V}_{2} \mathrm{O}_{5}$. Its needle-like nanocrystals form a nematic lyotropic liquid crystal, which was first investigated by Diesselhorst and Freundlich $[22,23]$ in the beginning of the 20th century. They reported the occurrence of birefringence of anisotropic crystallites of vanadium pentoxide when subjected to flow or to an electric field. It was concluded that both mechanisms had the same origin, application of a force to orient the elongated, needle-like crystallites that then exhibited a macroscopic birefringence. After the removal of the force, the system relaxed to yield an isotropic appearance. It has often been reported that a newly prepared $\mathrm{V}_{2} \mathrm{O}_{5}$ sol is initially isotropic, while it takes time to observe the development of nematic tactoids [24], as seen in Figure 4.

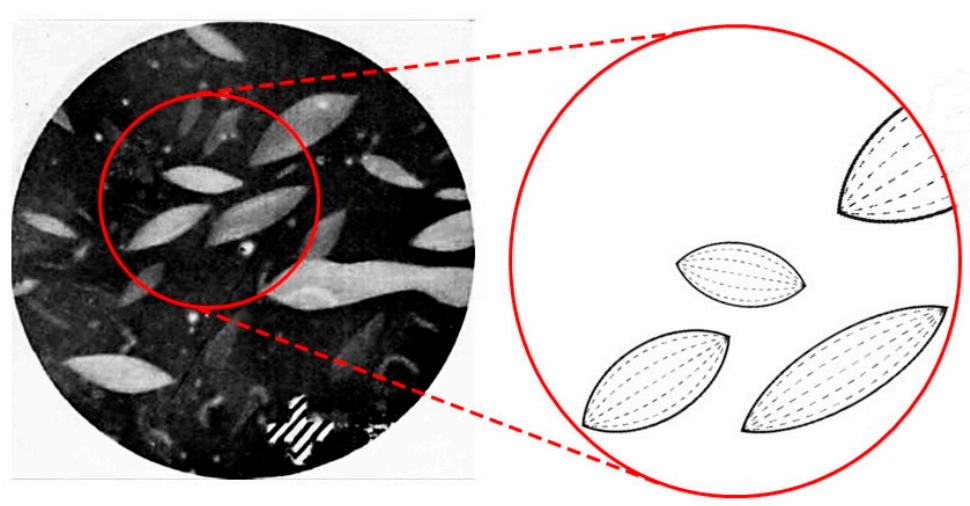

Figure 4. Formation of nematic tactoids in a preparation of vanadium pentoxide, $\mathrm{V}_{2} \mathrm{O}_{5}$ (reproduced with permission from Reference [24]), and corresponding needle crystallite orientation within some tactoids.

The phase formation largely depends on the preparation conditions and history of $\mathrm{V}_{2} \mathrm{O}_{5}$. This is related to the aging of freshly prepared sol and depends on concentration, temperature and possible electrolyte addition. The formation of the nematic phase is enhanced for large $\mathrm{V}_{2} \mathrm{O}_{5}$ concentrations and higher temperatures. The length of the colloidal vanadium pentoxide particle increases at a constant width of approximately $10 \mathrm{~nm}$ from the nanometer range to a few micrometers. This is accompanied by a sol-gel transition [25]. Electric field application in the nematic phase indicates that the system has a negative dielectric anisotropy, $\Delta \varepsilon<0$. This implies that in contrast to standard calamitic nematics with positive anisotropy, the director would switch from homeotropic to planar under electric field application. The phase sequence as a function of increasing concentration of $\mathrm{V}_{2} \mathrm{O}_{5}$ is isotropic-biphasic-uniaxial nematic for the fluid suspensions. For further concentration increase, a gel transition is observed and the uniaxial nematic gel is transformed into a biaxial nematic gel [26].

Similarly, aluminum oxyhydroxide, $\mathrm{AlOOH}$, forms nematic tactoids, which on merging exhibit a typical nematic Schlieren-texture [27]. $\mathrm{M}_{2} \mathrm{Mo}_{6} \mathrm{X}_{6}$, with the metal from the alkalimetal group $\mathrm{M}=\mathrm{Li}$, 
$\mathrm{Na}, \mathrm{K}$ and $\mathrm{X}=\mathrm{Se}, \mathrm{Te}$, from the chalcogens group, also represents a general group of inorganic LCs with nematic phases. Crystallites exhibit lengths of approximately several micrometers, and Schlieren-textures, as well as sometimes thread-like textures [28], can be observed when these are dispersed in an isotropic solvent, for example methylformamide. The formation of smectic phases has also been observed. This was shown for FeOOH and for tungstic acid $\mathrm{H}_{2} \mathrm{WO}_{4}\left(\mathrm{WO}_{3} \bullet \mathrm{H}_{2} \mathrm{O}\right)$ by the observation of steps in the textures of droplets, indicating smectic layering [29]. A more detailed overview about the structures of anisotropic crystallites, their preparation and the conditions employed to form liquid crystalline phases was published in a review by Sonin [30]. It appears that besides phase diagrams, textures and structures, there has been little work on such systems with respect to modern experimental techniques or applications by self-assembly for nanotechnology. Maybe it can be fruitful to revisit these systems from the different perspectives available today.

\subsection{Clays}

These natural soil materials of micro- and nano-meter dimensions present high shape anisotropy and contain hydrous aluminum phyllosilicates. Typically, the particles are plate-like, with the plate thickness in the nanoscale. In 1995, Mourchid and co-workers [31] reported an interesting study of aqueous suspensions of clay particles. However, they did not clearly identify a liquid crystalline phase. In 2009, Paineau and co-workers [32] published a paper about a highly diluted (5\% volume fraction) aqueous suspension of disk-shaped natural beidellite clay (a phyllosilicate), where a first-order isotropic to nematic phase transition was identified. The optical birefringence of these suspensions $\left(\sim 10^{-4}\right)$ is smaller than that from usual micellar lyotropics. The nematic phase may be aligned by electric and magnetic fields and also by shear. The stabilization of a lyotropic structure is assured in an aqueous medium by the existence of electrical charges on the surface of the particles and the hydration of the particles.

More types of clays in aqueous suspensions showed liquid crystalline behavior: bentonite, an aluminum phyllosilicate clay consisting mostly of montmorillonite [33] (Figure 5a), laponite, a synthetic layered magnesium silicate [34] (Figure 5b), and imogolite, an aluminum silicate [35,36]. The imogolite particle has a hollowed cylindrical shape with diameter of about $2 \mathrm{~nm}$ and length of the order of hundreds of nm. An interesting, and until now not fully understood behavior of imogolite suspensions, is the presence of a regular streaked texture, observed in the polarizing optical microscope, that resembles textures from cholesteric ordering. The imogolite particles do not have any chiral component and the chiral arrangement (if demonstrated by other experiments) should be due to a particular packing of the cylinders [36]. This type of texture may also originate by a nematic ordering in gels [37]. Aqueous suspensions of nontronite clay also showed a nematic to isotropic phase transition at low (below $10^{-3} \mathrm{M} / \mathrm{L}$ ) ionic strengths [38].

From the theoretical point of view, Onsager's approach [39] qualitatively explains the tendency of the plate-like clay particles to align in an aqueous suspension. However, the liquid crystalline behavior is not observed in concentrated suspensions, where phase segregation occurs. Polydispersity is also an issue that must be addressed when a suspension of clay particles in a solvent with liquid crystalline behavior is aimed at. Usually, a size separation procedure is needed before the preparation. 

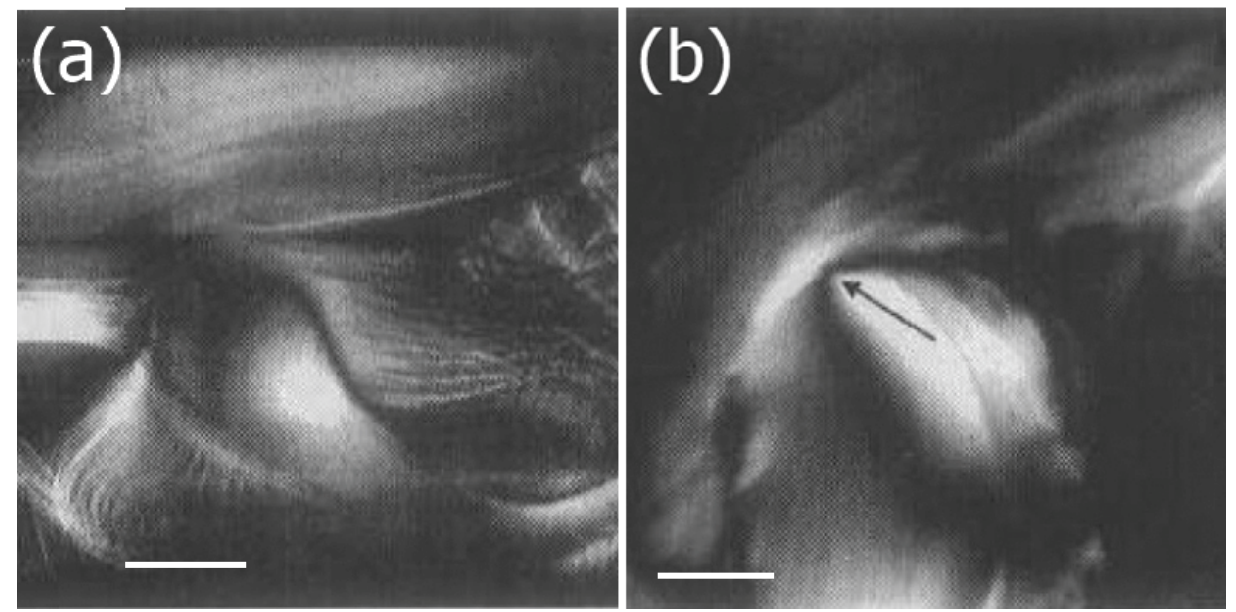

Figure 5. Nematic texture of different clays, (a) bentonite and (b) laponite (reproduced with permission from Reference [34]). Nematic textures for these materials are generally much less pronounced and typical than those for calamitic thermotropic liquid crystals. White bars correspond to $0.2 \mathrm{~mm}$ in (a) and $100 \mu \mathrm{m}$ in (b).

\subsection{Tobacco Mosaic Virus (TMV) and Other Viruses}

The tobacco mosaic virus can be seen as the prototype of a rigid rod system. It is very straight, with a constant length of $18 \mathrm{~nm}$ and an often close to monodisperse length distribution round $300 \mathrm{~nm}$. The aspect ratio is thus about 15 , and the system is ideally suited to test the Onsager theory [40], see Figure 6. The TMV is a right-handed single-stranded RNA virus which infests the leaves of tobacco, but also other plants, which is clearly visible through a pronounced and characteristic discoloration. Discovered toward the end of the 19th century by Mayer [41], it was first thought to be bacterial, but was later independently shown by Iwanowski [42] and Beijerinck [43] to be of different origin, for which the latter coined the term "virus". It was not until the 1930s that electron microscopic evidence was produced [44], and in 1936, Bawden et al. [45] had already reported the lyotropic liquid crystalline behavior of the tobacco mosaic virus.

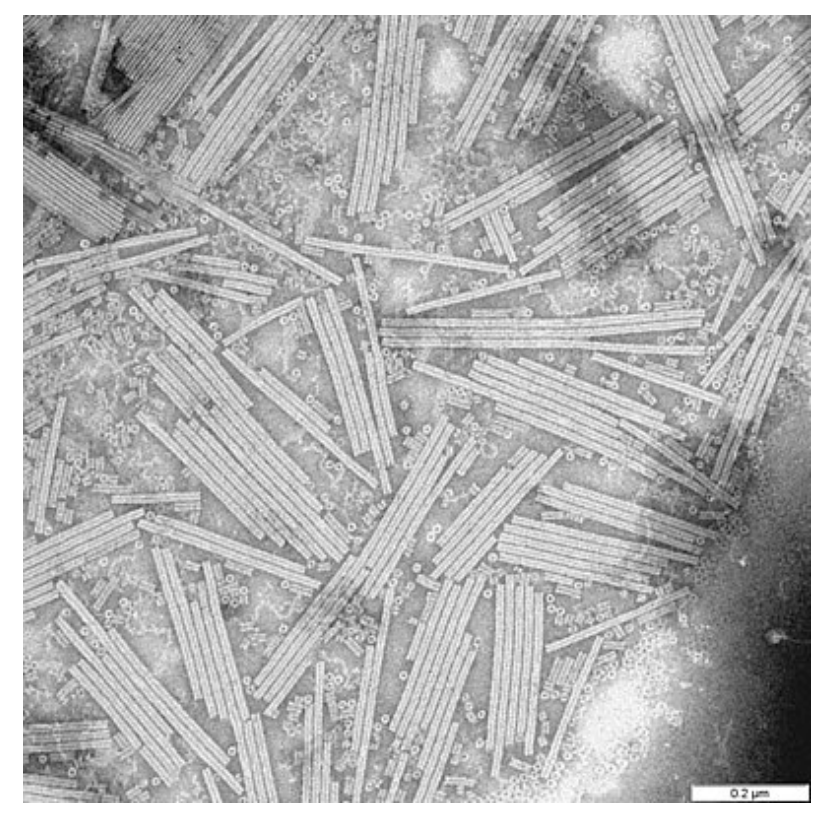

Figure 6. Electron microscopy image of tobacco mosaic viruses (TMV), showing an aspect ratio of approximately 15. The scale bar indicates $0.2 \mu \mathrm{m}$ (reproduced from Wikimedia Commons, with no author name supplied). 
From the magnetic field aligned nematic phase, Oldenbourg et al. [46] produced small-angle diffraction patterns which allowed the determination of the order parameter $\mathrm{S}$. The X-ray scattering for samples of increasing TMV concentration showed transitions from the isotropic phase at low concentrations, passing through a typical isotropic/nematic two-phase region to a pure nematic phase at high concentrations. The order parameter $S$ within the nematic phase changed from about $S=0.7$ at the transition to close to perfect order of the long axis of the TMV S $=1$ at rather high concentrations. This is indeed in accordance with predictions by the Onsager model. A very detailed study of the liquid crystalline behavior and physical properties of the TMV lyotropic nematic phase was carried out by Fraden et al. [47]. They measured the sample birefringence not only as a function of concentration and temperature, but also for varying ionic strength and different polydispersity. From these investigations, it was concluded that the stability of the nematic phase of tobacco mosaic virus suspensions is predominantly determined by electrostatic repulsion. Attractive van derWaals forces between the TMV rods supposedly play a much less important role. This provides an indication that the transition from isotropic to nematic is practically based on excluded volume effects. This in turn explains why the predictions of Onsager theory work very well for the TMV liquid crystal, because the theory is based on repulsive steric interactions, ignoring attractive forces between the colloidal particles. Graf and Löwen [48] later predicted the detailed phase diagram of the tobacco mosaic virus from theory and the use of computer simulations. They also described a further transition into smectic phases and colloidal crystals. Different virus suspensions, for example rod-like or semiflexible filamentous bacteriophage $\mathrm{fd}$, have been reported to also exhibit chiral nematic or cholesteric order [49], as well as smectic layering [50], respectively. An overview can be found in the reviews of References [51,52].

We shall see below that novel trends in TMV lyotropic phase research have applicational potential in the production of silica nanostructures through templating. Another more fundamental aspect can be the experimental study of the phase behavior of mixtures, for example of rods and spheres [53], but also other systems like rods and plates, and even rod-rod systems with very different aspect ratios. This would be especially of interest in combination with computer simulations. Other novel aspects may be found in biological and chemical sensing or directed drug delivery.

\subsection{Lyotropic Phases from DNA}

The DNA macromolecule is a charged anionic polyelectrolyte formed by a right-handed double helix. Small fragments of DNA have a cylindrical shape of about $2 \mathrm{~nm}$ of diameter and variable lengths (typically $\sim 50 \mathrm{~nm}$ ). These fragments can be dispersed in water and present lyotropic liquid crystalline phases [54]. Increasing the DNA concentration in aqueous solutions (depending on the ionic strength and DNA persistence length), the phase sequence experimentally observed is: isotropic, blue phase, cholesteric, columnar hexagonal and crystalline (Figure 7). Disclinations and dislocations were observed in textures of aqueous DNA solutions, identifying the cholesteric phase [55]. Besides the texture inspection, measurements of the circular dichroism were performed to identify this mesophase.

More difficult to be identified is the blue phase, since it exists in a narrow range of temperature and DNA concentration, being optically isotropic. The electron microscopy of freeze-fracture replicas was used to identify the macromolecular arrangement in a double-twist ordering within small cylindrical domains. The optically anisotropic columnar phase was identified by different experimental techniques, mainly X-ray diffraction. The transition from the cholesteric to the columnar phase was shown to be of first-order or continuous. The same DNA solution may show both types of phase transition and, until now, the conditions defining one or the other type of transition are not known. Solutions with long DNA fragments ( $\sim 70 \% \mathrm{w} / \mathrm{v}$ - comparable to that of in vivo systems) showed a cholesteric phase, with concentration-dependent pitch, and another two-dimensional (2D) phase that resembles the smectic thermotropic phase [56]. 


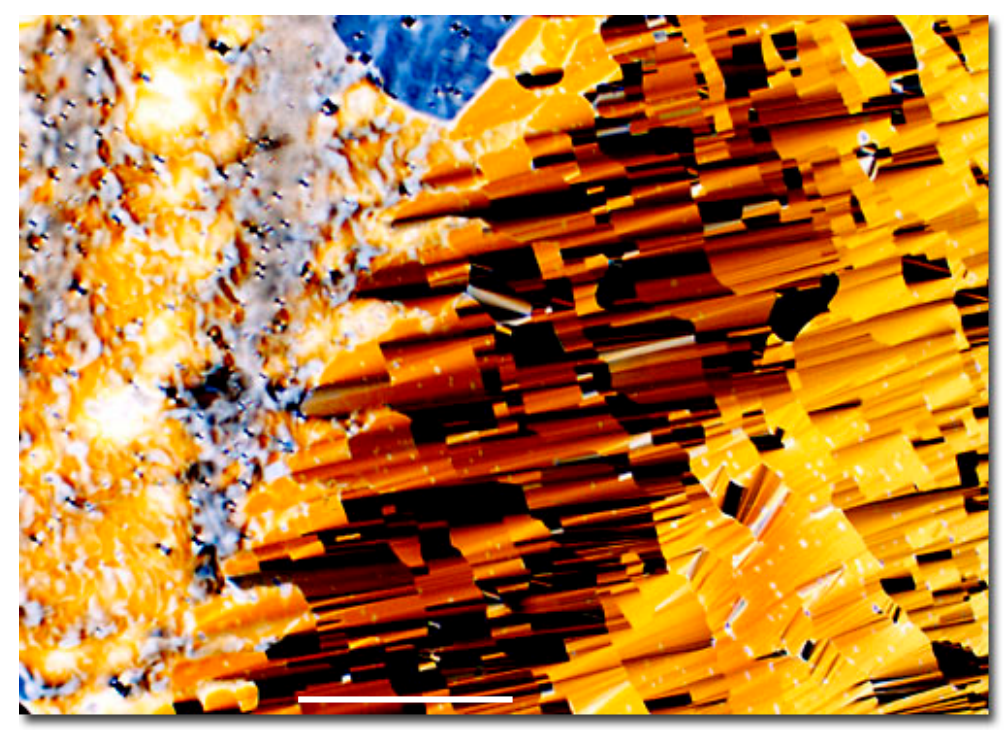

Figure 7. Transition region of the cholesteric (left) and the high-density region phases (right) in solutions of rod-like DNA molecules (reproduced with permission from Molecular Expressions at the Florida State University Research Foundation. The image can be found at the website https: //micro.magnet.fsu.edu/dna/pages/transition3.html). White bar corresponds to about $300 \mu \mathrm{m}$.

Not only long DNA fragments were shown to present liquid crystalline phases. Short fragments (about 8 base pairs) in aqueous solutions with RNA presented columnar and cholesteric phases [57]. The local structure is stabilized due to base stacking forces that promote the end-to-end aggregation of duplexes. An interesting behavior was observed in drying droplets of DNA (persistence length of $\sim 50 \mathrm{~nm}, 48 \mathrm{k} \mathrm{pb}$ ) aqueous solutions, where "coffee rings" are formed [58]. The DNA macromolecules accumulate in the droplet edge, forming a lyotropic liquid crystal with concentric-chain orientations.

The atomic arrangement and charge distribution present in DNA fragments open many possibilities of liquid crystalline structures with these building blocks. Salamonczyk and co-workers [59] reported an interesting result about the presence of the smectic-A phase in an aqueous suspension of double-stranded DNA fragments. To achieve this, they increased the DNA flexibility by introducing a spacer in the middle of each duplex. Storm and co-workers discussed the formation of a columnar liquid crystalline structure of self-assembled DNA bottlebrushes [60]. The building block of this structure is made of DNA as the backbone molecule and $\mathrm{C}_{4} \mathrm{~K}_{12}$ protein polymers as the side chains.

Recently, Brach and co-workers reported a study where important differences in the DNA spatial structure were observed between free DNA and DNA organized in a lyotropic liquid crystalline arrangement [61]. The relations between the liquid crystalline structure and the functionality of living processes involving DNA still challenges researchers and opens a fascinating field of investigation. This last aspect inspires researchers to explore the relations between the liquid crystalline structure and the functionality of living processes involving DNA.

\subsection{Lyotropic Cholesteric Cellulose Derivatives and Cellulose Nanocrystals}

Cellulose is composed of $\beta$-D-glucopyranose units covalently linked with (1-4) glycosidic bonds. Cellulose nanocrystals (CNCs) are obtained from natural cellulose fibers. They are hydrophilic but can be surface functionalized to change their properties in the presence of different solvents [62]. CNCs are stiff, lath-like nanoparticles, with a typical diameter as small as $\sim 6 \mathrm{~nm}$, depending on the preparation method [63], and a length of about $100 \mathrm{~nm}$.

Aqueous suspensions of cellulose nanocrystal particles, chemically prepared to avoid electrostatic stabilization and favoring the steric interaction [64], gave rise to a cholesteric mesophase (see Figure 6), with the typical fingerprint texture [65]. The cholesteric liquid crystalline phase occurs at a volume concentration of nanoparticles of about 10\% [66]. One interesting application of the CNCs solution 
showing the cholesteric phase is that the mixture can be dried, maintaining the chiral structure, to make films that acquire photonic band gap properties [67].

Cholesteric properties of suspensions of cellulose nanocrystals can be modified by decorating the nanoparticles with polymers [68]. The surface chemistry of the nanoparticles and interacting forces modifies the phase diagrams and the pitch of the suspensions. Long-pitch chiral mesophases were obtained with a decrease in the surface charge of the particles, decreasing the particle-particle interaction [69]. This mesophase is highly viscous and is located in the vicinity of a biphasic region.

Cellulose-based lyotropic mixtures may also stabilize mesophases [70]. Solutions of cellulose tricarbanilate in methyl acrylate and methyl methacrylate were shown to stabilize nematic and cholesteric mesophases at specific relative component concentrations and temperatures [71,72]. Lyotropic mesophases were also obtained in cellulose derivatives (with hydroxypropylcellulose (Figure 8a-d) and ethyl-cellulose) in inorganic solvents [73]. Cellulose acetate phthalate/hydroxypropyl cellulose blends in $\mathrm{N}, \mathrm{N}$-dimethylacetamide showed lyotropic polyphormism under proper temperature and relative concentration conditions [74].

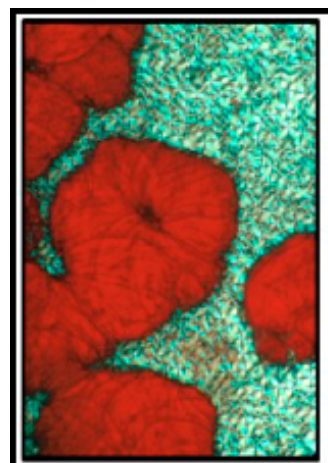

(a)

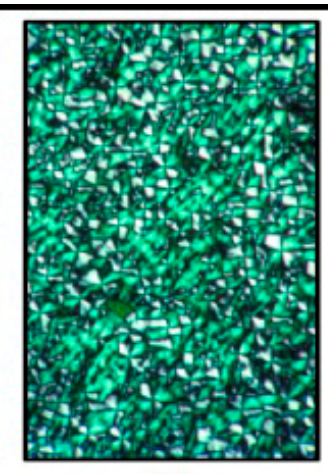

(b)

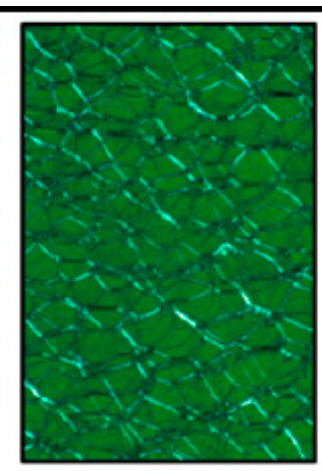

(c)

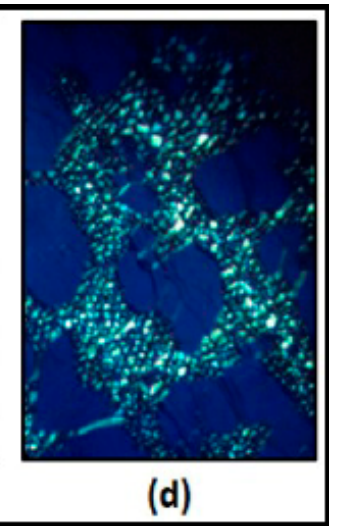

(d)

Figure 8. Lyotropic textures from (Hydroxypropyl) cellulose (HPC)/water in a polarized microscope: (a) $\sim 45 \% \mathrm{HPC}$, planar and focal conic textures, (b) 55\% HPC, focal conic texture, (c) 55\% HPC, oily streak texture, (d) $\sim 65 \%$ HPC, planar and focal conic textures (reproduced with permission from Reference [65]).

\subsection{Nanotubes, Nanorods and Nanowires}

Most of the systems relating to liquid crystalline behavior and nanotubes, nanorods or nanowires are composites, where the nanomaterial is dispersed in a thermotropic liquid crystal. This is often the nematic phase [75-78], occasionally also a smectic phase, often already with an additional functionality available, such as ferroelectric liquid crystals [79]. Such nanomaterials have been dispersed in lyotropic liquid crystals to a much lesser extent [80-83], often in the hexagonal phase for compatibility reasons. Thermotropic liquid crystals are used with carbon nanotubes to directionally orient the nanotubes or nanorods to exploit their extraordinary properties in a predetermined way as an addition to properties provided by the liquid crystal itself. On the other hand, lyotropic liquid crystals may be used as templates for materials in nanotechnology, often washing the liquid crystal out after the templating process. For example, nanowires and nanorods have been produced by synthesis in the lyotropic liquid crystalline state of $\mathrm{TiO}_{2}$ [84] and $\mathrm{ZnO}$ [85].

In addition to the dispersions of nanotubes, nanorods or nanowires in thermotropic or lyotropic liquid crystal phases, these materials can in fact also form lyotropic liquid crystals by themselves through dispersion in an isotropic solvent. The behavior is often very similar to that observed for needle-like inorganic liquid crystals, or also the tobacco mosaic virus, and largely follows the description by Onsager's theory. At low concentrations of nanomaterials, an isotropic dispersion is observed, that changes to a biphasic region for increasing concentration, eventually forming a nematic lyotropic phase. For nanotubes, this was first theoretically predicted by Somoza et al. [86]. 
Experimental evidence followed soon for functionalized multi-wall carbon nanotubes (MWNT) in water $[87,88]$, showing a nematic phase above 4 vol\% MWNTs. Instead of covalent functionalization, systems of nanotube-adsorbed DNA were also used, providing the electrostatic repulsion favorable for LC formation [89,90]. Electrostatic repulsion for better dispersion was also used by Davis et al. [91] and Rai et al. [92] when choosing strong acids as isotropic solvents, which led to a protonation of the tube walls, instead of nanotube functionalization or decoration.

$\mathrm{ZnO}$ is a wide bandgap semi-conductor, which in nanowire form can exhibit liquid crystalline behavior as a lyotropic nematic $[93,94]$. Similarly, $\mathrm{TiO}_{2}$ nanowires can assemble into liquid crystal phases [95]. Semiconductor rods of cadmium selenide, CdSe, can be produced with excellent monodispersity and a ratio of length to width of generally 40 to $6 \mathrm{~nm}$, respectively. These are thus ideal candidates to exhibit not only nematic (Figure 9), but also smectic/lamellar ordering of lyotropic liquid crystals, as demonstrated in References [96,97]. The general potential of using nanomaterials in liquid crystals, either to tune the LC properties, to add functionality or to transfer liquid crystal order onto nanomaterials during synthesis or self-assembly in nanotechnology, is enormous. It can be expected that a whole new range of fundamental insights as well as technical applications are still to come in the future.

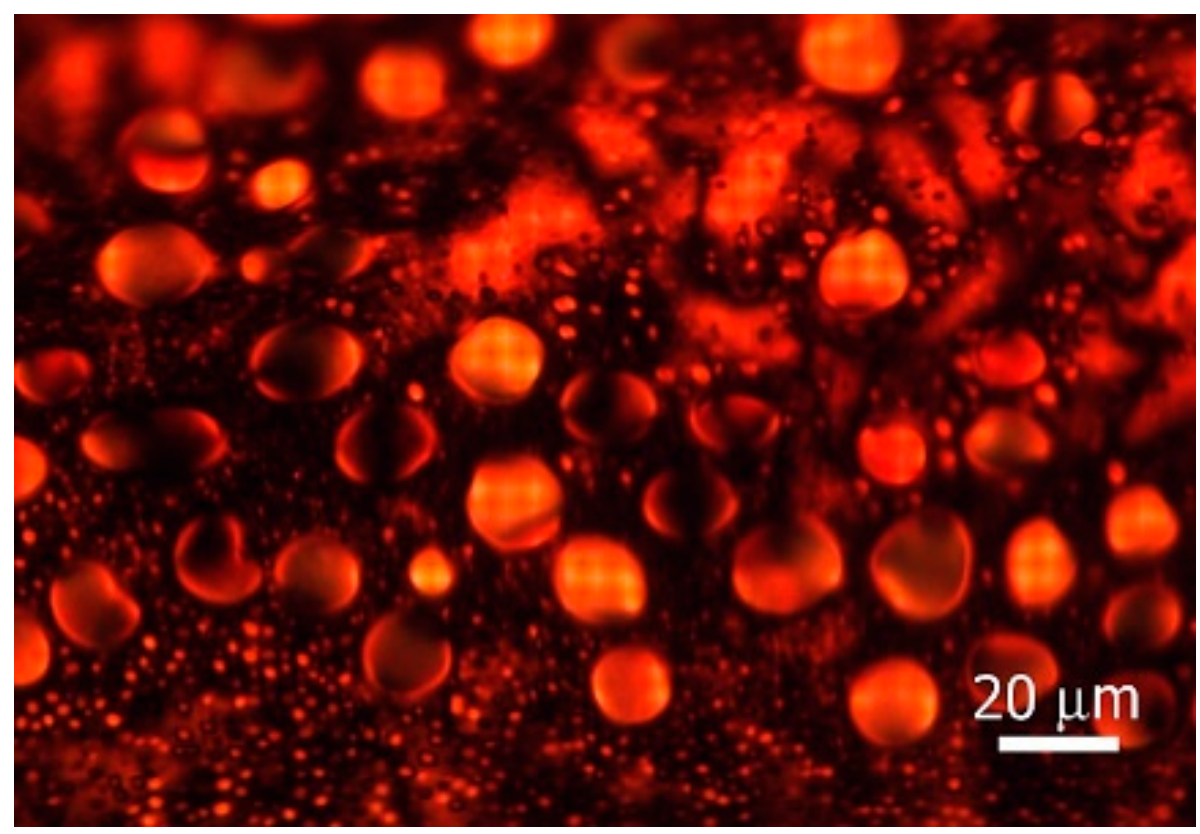

Figure 9. Nematic liquid crystal droplets forming on evaporation of the solvent from a cadmium selenide (CdSe) nano-rod solution (reproduced with permission from Reference [96]).

\subsection{Graphene Oxide and Other 2D Materials}

Similar to the rod-like and disc-like shapes of calamitic and discotic thermotropic liquid crystals, the analogue to lyotropic nanotubes would be graphene. Graphene itself has been shown to exhibit a nematic liquid crystal phase only in the protonated environment of strong chlorosulphonic acid [98]. A material more similar to the $\mathrm{COOH}$-functionalized nanotubes is graphene oxide (GO), which readily shows liquid crystalline behavior over large concentration ranges $[99,100]$ in a multitude of isotropic solvents, including water. In Figure 10, a well-aligned sample is shown, which exhibits optical properties like a standard calamitic nematic liquid crystal, but with the director in the direction of the sheet normal. The general phase behavior is as discussed for other lyotopic systems: an isotropic phase is followed by a two-phase region, ending in a fully developed nematic phase for increasing graphene oxide concentration. The details of the phase diagram are, on the other hand, dependent on the average size of the GO flakes [101,102], their polydispersity, the polarity of the solvent [101,103] and confinement conditions [101]. It has been shown that graphene oxide liquid crystals respond to applied 
electric fields [104,105] and that an electro-optic response can be achieved, which is based on a large Kerr effect [106,107], i.e., an induced birefringence proportional to the square of the applied electric field. The Kerr response times are at present longer than those of the well-discussed thermotropic Blue Phases, due to the higher viscosity of GO-LCs. So far, graphene oxide liquid crystals are by far the best studied of the lyotropic liquid crystals made from 2D materials, and their properties have been summarized in a number of review articles [108-110], although it should be mentioned that here, there are also still many open questions. One of these, which has, for example, been addressed via texture and dielectric studies, is the observation of mixtures of thermotropic nematics with GO [111]. There is some evidence $[111,112]$ that on heating such a dispersion into the isotropic phase of the thermotropic LC, this acts as an isotropic solvent to facilitate the formation of a lyotropic GO liquid crystal phase. This is a very interesting topic, as it implies a thermotropic nematic to lyotropic nematic phase transition, which is not accompanied by any transition enthalpy. This should also be attractive for theoretical interpretation.

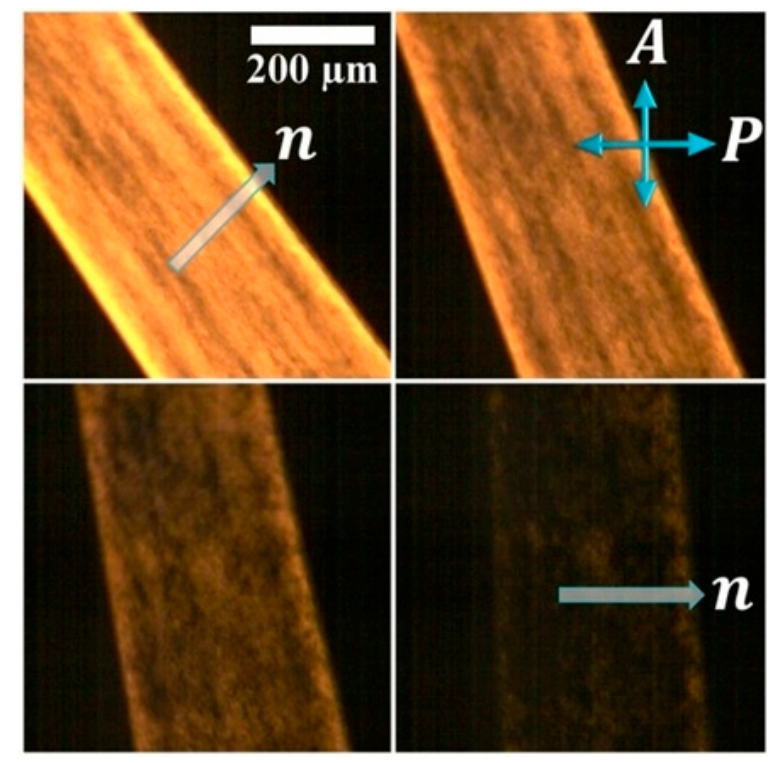

Figure 10. A lyotropic nematic graphene oxide phase can be oriented by a narrow, untreated glass channel. The quality of orientation is demonstrated by rotation of the sample between crossed polarizers. The director is indicated by $\boldsymbol{n}$ (reproduced with permission from Reference [37]).

Lastly, it should also be mentioned that other 2D materials can exhibit liquid crystalline phases in isotropic solvents. One of these is reduced graphene oxide (rGO) [113,114], which regains a certain amount of the conductive behavior observed for graphene, which is absent from graphene oxide. Reports have also been published for molybdenum disulphide, $\mathrm{MnO}_{2}$ [115] and Mxenes [116] . A number of other possible candidates have yet to be investigated further [117]. The topic of graphene oxide liquid crystals, their properties, and dispersions with other lyotropic liquid crystal classes, will certainly be an exciting one over the next years to come. Also, with respect to possible applications, for example as fibers [118,119], in tuneable photonics [120], nanofiltration [121] or reflective displays [122].

\subsection{Chromonics}

Chromonics are rigid aromatic molecules, with hydrophilic ionic and hydrogen-bond groups located in the peripheries of the molecule $[123,124]$. $\pi$-stacking interactions between these flat molecules favor packing. In the presence of a polar solvent (e.g., water), they stack face to face in columns of different aggregation numbers. The (anisometric) columns consist of the building blocks of lyotropic liquid crystals (Figure $11 \mathrm{a}-\mathrm{c}$ ). Dyes, drugs and even nucleic acids are examples of this type of 
molecule [125]. Different mesophases were identified in mixtures with this type of molecule: uniaxial nematic [126], hexagonal [127] and lamellar-type structure (proposed for the diethyl ammonium flufenate) [128]. The aggregation of chromonic molecules is isodesmic, where the energy between molecules in a stack is independent of the number of molecules [129]. The addition of salts (e.g., $\mathrm{NaCl}$ ) to the lyotropic nematic phase of cromolyn aqueous solutions shifted the nematic to isotropic phase boundaries upwards [130].

Decreasing Energy (Increasing Concentration/Lowering Temperature)

(a) Isotropic Phase

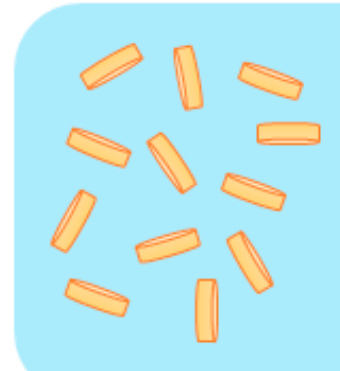

(b) Nematic Phase

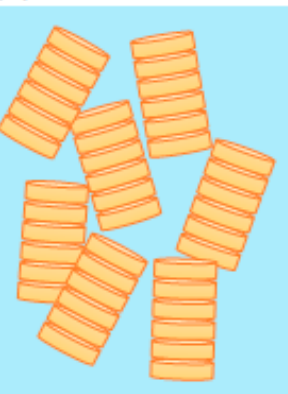

(c) Columnar Phase

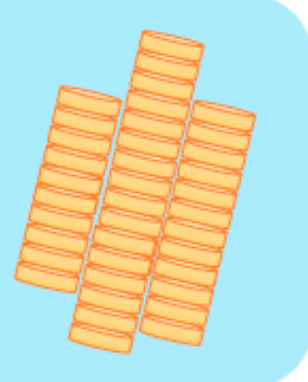

Figure 11. Typical structures of chromonic liquid crystal mesophase (reproduced with permission from https://core.ac.uk/download/pdf/54848113.pdf). (a) Isotropic, (b) nematic and (c) columnar phase.

From the theoretical point of view, besides the classical Onsager's approach, a model considering a competition of charge-like, long-range repulsion and anisotropic short-range attraction among molecules was recently proposed [131]. The nematic and hexagonal phases were obtained in the framework of this model, even at a small volume fraction of molecules, and correlations between the elastic response and stack growth were obtained. The elasticity of chromonic nematics was theoretically investigated (Monte Carlo simulations and Onsager-like model), inspecting the behavior of the Frank elastic constants, $\mathrm{K}_{11}, \mathrm{~K}_{22}$ and $\mathrm{K}_{33}$, as a function of temperature and molecules' volume fraction [132]. The dependence of the elastic constants with temperature and molecules' volume fraction agree with the experiments. The elastic characteristics of chromonics is evidenced in experiments where the liquid crystal is confined in small droplets (typically from 1 to $100 \mu \mathrm{m}$ ) [133]. A very small twist elastic modulus in the nematic phase seems to be responsible for the appearance of a chiral-twisted bipolar configuration in confined conditions. Chromonic nematics are interesting systems to study topological defect cores in disclinations of $+1 / 2$ and $-1 / 2$ strengths, that extend to micrometric dimensions [134].

Recently, molecules of the chromonic Sunset Yellow (SSY) were added to classical amphiphilic lyotropic mixtures presenting the biaxial nematic phase [135]. It was shown that SSY exhibits a chaotropic character. Moreover, SSY causes an increase of the micellar shape anisotropy and, consequently, an increase of the biaxial nematic phase domain, with respect to the phase domain of the undoped mixture.

\subsection{Polar Lyotropic Lamellar Phases}

It took about half a century from the discovery of the first ferroelectric crystal, Rochelle salt [136], for the first fluid material, the chiral smectic $C^{*}$ phase, to be discovered [137]. It is already remarkable in itself that a fluid material can exhibit a spontaneous polarization, although, due to the SmC ${ }^{*}$ helix, in its bulk state, it may rather be called helielectric, as true ferroelectricity requires this polarization to be switchable between two stable states. This was demonstrated shortly afterwards with the surface stabilized ferroelectric state [138] and has initiated one of the most active topics in liquid crystal research in the last century. So far, this is all related to thermotropic materials. On the other hand, it was long known that thermotropic and lyotropic phases do show a certain amount of analogy. Both exhibit orientationally ordered nematic phases. The lamellar $L \alpha$ phase is the lyotropic analogue of the 
thermotropic SmA phase. So, why was there no tilted lamellar phase, a lyotropic equivalent of the rather common SmC phase? This was observed for the first time by Schaheutle and Finkelmann [139] and was demonstrated clearly by X-ray diffraction. A second report followed quite a number of years later [140]. These appear to have been the only confirmed cases of a tilted fluid lamellar phase. It was not until 2013 when a chiral amphiphilic molecule was shown to exhibit a lyotropic analogue of the ferroelectric SmC* phase [18] when added to an isotropic solvent, water or formamide, over a certain range of concentrations.

The fluid tilted lamellar phase was verified via X-ray diffraction and typical textures could be observed, such as a smectic Schlieren-texture (Figure 12a), broken fan-shaped textures (Figure 12b), and in the surface stabilized geometry, a domain texture, which could mutually be brought to extinction when rotated by twice the tilt angle between crossed polarizers (Figure 12c,d). Chirality could be demonstrated by a typical striped texture due to the helical superstructure, just as observed for the thermotropic $\mathrm{SmC}^{*}$ phase. The pitch increased strongly when approaching the orthogonal phase (the SmA* analogue) on heating at a fixed concentration, which is also generally observed for the thermotropic case. But, the most striking evidence can be found in the ferroelectric electro-optic switching of the surface stabilized state. However, a direct measurement of the spontaneous polarization is not possible due to the overall ionic conductivity of the samples. Lastly, it should be mentioned that the electroclinic effect could also be verified for the orthogonal chiral $\mathrm{L}_{\alpha}{ }^{*}$ phase [141], which very much resembles that of the $S m A^{*}$ phase of thermotropics. Other amphiphilic molecules with a similar behavior have been synthesized since [142], and a detailed account of this topic can be found in the review of Reference [143]. The aspect of a conceptual transfer relating to physical properties and structures between thermotropic and lyotropic liquid crystals is certainly a very novel approach and opens up a whole field of future research in lyotropic liquid crystals.

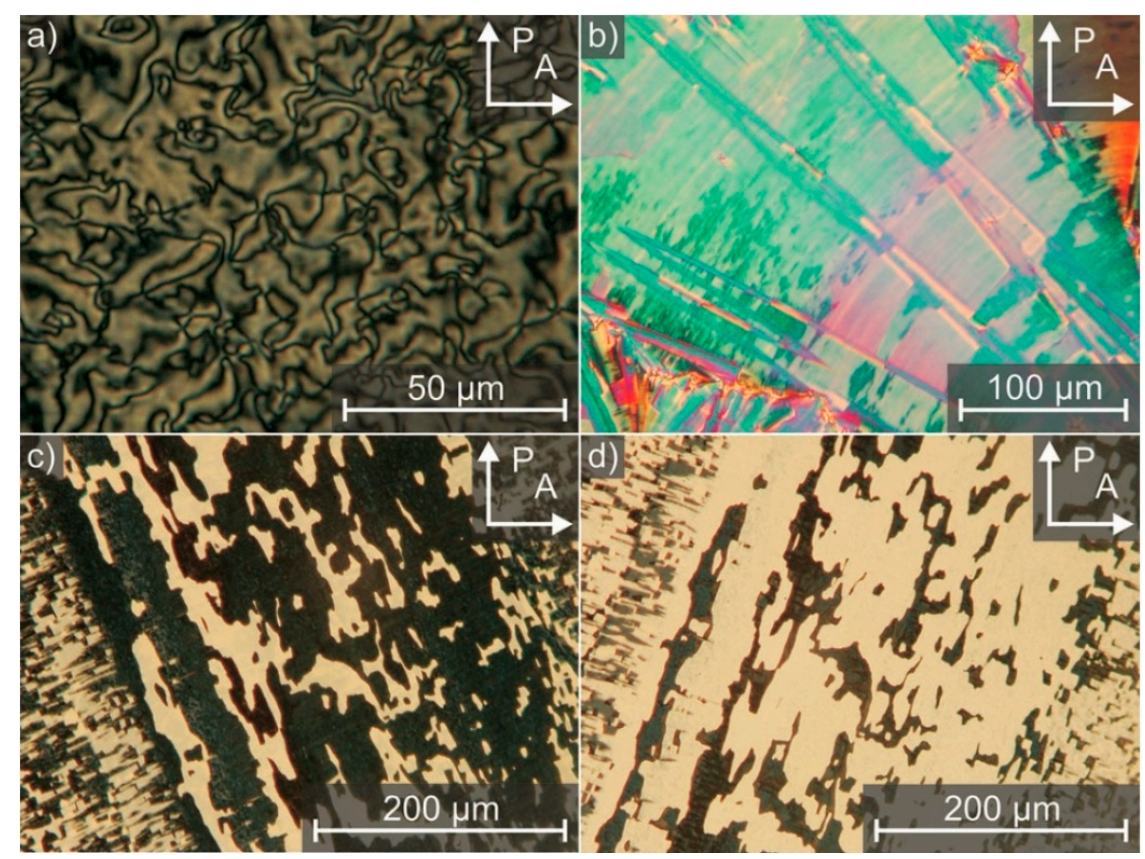

Figure 12. Different textures of the lyotropic $S m C^{*}$ phase. (a) $S m C^{*}$ Schlieren-texture, (b) broken fan-shaped chevron texture with typical zig-zag lines, and (c) and (d) surface stabilized SmC* domain texture, rotated by twice the tilt angle respectively, leading to mutually dark and bright domains (reproduced with permission from Reference [18]).

\subsection{Active and Living Lyotropic Nematics}

An emerging topic in liquid crystal research and especially lyotropic liquid crystals is active matter or living liquid crystals. Active matter $[144,145]$ in general are systems that are composed of a 
large number of constituents, each consuming or transforming energy for the reason of propulsion. These are thus intrinsic non-equilibrium systems. There is a wide variety of such systems found in soft and biological matter, for example a school of fish, bacteria or microtubules. They all have one property in common, they are self-organizing and exhibit collective, self-propelled motion. Liquid crystal-based active matter has recently attracted much increasing interest [146], due to fascinating phenomena observed that are absent in passive liquid crystals [147].

Active liquid crystal systems that are often studied include bacterial suspensions [148,149], microtubule-motor protein systems [150,151] and actin-motor protein systems [152-154].

A quite different system has been proposed, called "living liquid crystals" [155-158]. These are of particular interest to lyotropic liquid crystals, as they represent swimming, live bacteria in a lyotropic nematic phase (Figure 13). The latter have been shown to be supporting bacteria life [159], which is not the case for thermotropic nematic liquid crystals. Lavrentovich and co-workers [155] demonstrated experimentally that bacteria can sense director field deformations. They showed that for pure splay and pure bend deformations, the motion of the bacteria was equally probable in either direction of the director field. For regions with splay-bend deformations, like in the vicinity of topological defects, the motion was directed towards the positive $s=1 / 2$ defect and avoiding the negative $s=-1 / 2$ one. By the use of predetermined director patterns, they directed the motion of bacteria and exerted a directing influence on the otherwise chaotic bacterial motion. Active and living liquid crystals exhibit a plethora of fascinating phenomena, spatio-temporal patterns and prospects for biological and biomedical applications. It is thus very likely that this field of lyotropic liquid crystal research will thrive in the future, not only in experiment but also in theory, simulations and applications.

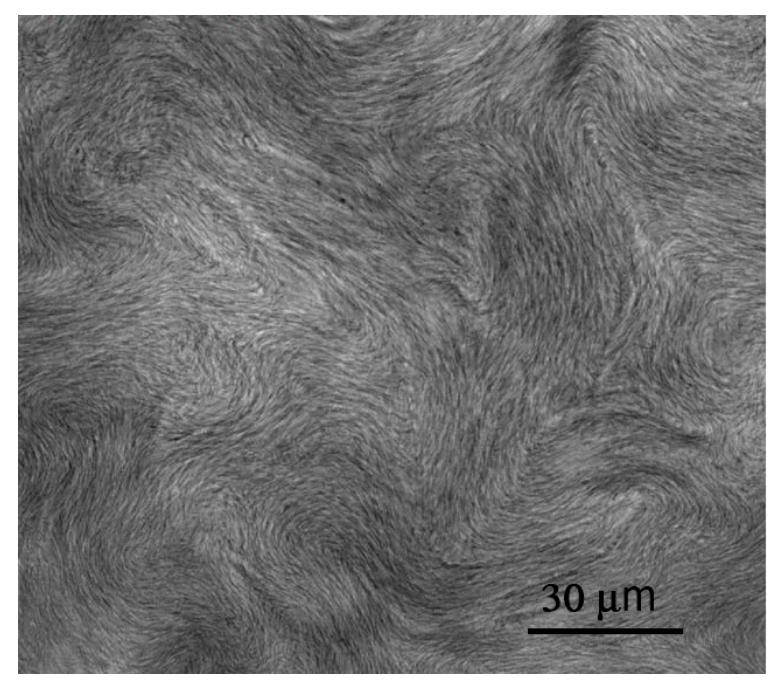

Figure 13. Texture of a living liquid crystal with disclination pairs. The bacteria are aligned along the local nematic director, seen by the lines in the textures (reproduced with permission from Reference [155]).

\subsection{Applications}

To the general public, liquid crystals are often primarily known through their electro-optic applications in displays, light shutters, or optical light modulators. Lyotropics are generally quite unheard of, despite of the fact that we use them on a daily basis. Obviously, a short paragraph on the applications of lyotropic liquid crystals cannot be all encompassing. Besides the various applications in the food and cosmetics industries, as well as detergents [160-164], we will here give an indicative overview of some other, possibly more modern applications.

One of these topics is drug delivery, which is somewhat related to some aspects encountered in the food and cosmetics industry in terms of the targeted and controlled release of an active ingredient. For this, often lyotropic phases can be exploited to trigger the release, for example through a change 
of the $\mathrm{pH}$ [165], or even by light irradiation [166], where the release is started by molecular switches. For further information, we refer to some relevant reviews $[167,168]$ and citations therein.

Since the seminal work of Abbott and co-workers [169], liquid crystal sensors generally employ a molecularly triggered texture transition of a thermotropic liquid crystal from a dark to bright state (or vice versa) that indicates the absorption of a number of liquid, gas, or biological molecules within the liquid crystal [170]. But, there have also been some reports of lyotropic LC being used for sensing, for example chromonics for biological sensing applications [171], or lyotropic phases of DNA for enzymes [172] and other for antigens [173] and pathogens [174]. In general, particularly the fields of biologically relevant systems like biotechnology, biosensors, drug delivery and biomimetics [175] are of highlighted interest for lyotropic liquid crystals.

Further, the lyotropic phases have found their way into the templated synthesis and self-assembly for functional nanoparticles and nanotechnology. The use of nematic tobacco mosaic viruses has been suggested for the design of silica mesostructures. Exploiting the TMV as a template in the synthesis of inorganic frameworks with ordered porosity was demonstrated by Fowler et al. [176]. They described a method where ordered viruses were first silicated and then thermally removed via biodegradation. This produced silica structures with ordered nanochannels of $20 \mathrm{~nm}$ diameter. The method of using a lyotropic structure for the synthesis of nanoparticles [177] and nanostructured materials [178] was quickly picked up and used for a variety of different systems [179,180] (Figure 14a-c). For further information, one may refer to a review article by Hegmann et al. [181] and references therein.

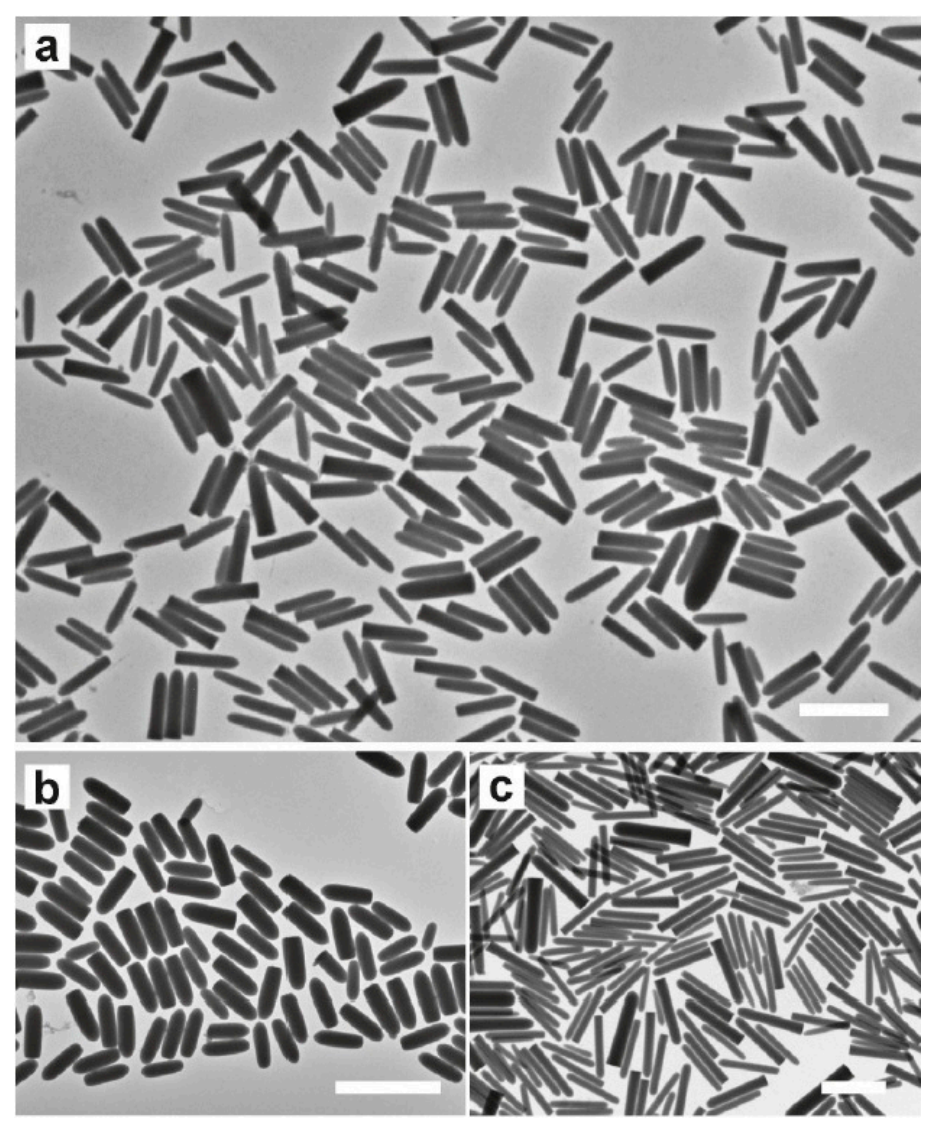

Figure 14. Transmission electron microscopy images of silica rods synthesized by templating a lyotropic phase. The scale bars are $2 \mu \mathrm{m}$. Different aspect ratios, $\mathrm{L} / \mathrm{D}$ can be obtained, for example $(\mathbf{a}) \mathrm{L} / \mathrm{D} \approx 5$, (b) $\mathrm{L} / \mathrm{D} \approx 3,(\mathrm{c}) \mathrm{L} / \mathrm{D} \approx 8$, by running the synthesis for different times. The anisotropy is ascribed to the anisotropic supply of reactants, leading to rod-like growth (reproduced with permission from Reference [182]). 
Lastly, one may want to mention some applications of dried cellulose nanocrystals, which firstly transfer liquid crystalline order onto dispersed functional nanomaterials and are subsequently dried to produce thin solid films. These can then be employed as chromonic films [183] due to the residual selective reflection of the cholesteric structure, or as plasmonic films with dispersed gold $[184,185]$ or silver [186] nanorods or nanowires, respectively. From the discussed selected examples, it becomes clear that lyotropic liquid crystals have significant potential for future applications, likely to be most intensified in the areas of biotechnology and biomedicine.

\section{Conclusions}

We hope that we could provide the reader with a short, yet hopefully interesting overview of some of the recent developments and novel trends in lyotropic liquid crystal research. There are certainly still a lot of unanswered fundamental questions in this field, materials developments to be explored and applications to be found, optimized and introduced to the market. This review of new trends in the field has hopefully sparked the interest of readers to explore some of the topics discussed in much more detail in the papers of this special issue, and maybe this issue will help in further bringing together the two fundamental fields of liquid crystal research, thermotropic and lyotropic systems, in the quest to develop an overarching general understanding of this fascinating aspect of soft matter.

Author Contributions: This review was written in equal parts by I.D. and A.M.F.N. All authors have read and agreed to the published version of the manuscript.

Funding: This research received no external funding.

Conflicts of Interest: The authors declare no conflict of interest.

\section{References}

1. Neto, A.M.F.; Salinas, S.R.A. The Physics of Lyotropic Liquid Crystals: Phase Transitions and Structural Properties; Oxford University Press: New York, NY, USA, 2005.

2. Petrov, A.G. The Lyotropic State of Matter: Molecular Physics and Living Matter Physics; Taylor \& Francis: London, UK, 1999.

3. Reinitzer, F. Beiträge zur Kenntniss des Cholesterins. Monatsh. Chem. 1888, 9, 421-441. [CrossRef]

4. Virchow, R. Myelinformen. Arch. Pathol. Anatom. Physiol. Klin. Med. 1854, 6, 572. [CrossRef]

5. Mettenheimer, C. Mittheilung in Betreff mikroskopischer Beobachtungen mit polarisirtem Licht. Correspondenzblatt Vereins Gemeinschaftliche Arb. Förd. Wiss. Heilkd. 1857, 24, 331-332.

6. Planer, J. Notiz über das Cholestearin. Ann Chem. 1861, 118, 25-27. [CrossRef]

7. Loebisch, W. Zur Kenntniss des Cholesterins. Ber. Deutsch. Chem. Ges. 1872, 5, 510-514. [CrossRef]

8. Rayman, M.B. Contribution à l'histoire de la cholestérine. Bull. Soc. Chim. Paris 1887, 47, 898-901.

9. Lehmann, O. Über fliessende Krystalle. Z. Phys. Chem. 1889, 4, 462. [CrossRef]

10. Markovitsi, D.; Mathis, A.; Simon, J.; Wittman, J.C.; Le Moigne, J. Annelides V: A New Type of Lyotropic Mesomorphic PHASE. Mol. Cryst. Liq. Cryst. 1980, 64, 121-125. [CrossRef]

11. Menger, F.M.; Littau, C.A. Gemini-surfactants: Synthesis and properties. J. Am. Chem. Soc. 1991, 113, 1451-1452. [CrossRef]

12. Menger, F.M.; Ding, J. Spiro-Tenside und -Phospholipide: Synthese und Eigenschaften. Angew. Chem. 1996, 108, 2266-2268. [CrossRef]

13. Schröter, J.A.; Tschierske, C.; Wittenberg, M.; Wendorff, J.H. Formation of Columnar and Lamellar Lyotropic Mesophases by Facial Amphiphiles with Protic and Lipophilic Solvents. J. Am. Chem. Soc. 1998, 120, 10669-10675. [CrossRef]

14. Fuhrhop, J.H.; Fritsch, D. Bolaamphiphiles form ultrathin, porous and unsymmetric monolayer lipid membranes. Accounts Chem. Res. 1986, 19, 130-137. [CrossRef]

15. Yu, L.J.; Saupe, A. Observation of a Biaxial Nematic Phase in Potassium Laurate-1-Decanol-Water Mixtures. Phys. Rev. Lett. 1980, 45, 1000-1003. [CrossRef]

16. Luckhurst, G.R.; Sluckin, T.J. (Eds.) Biaxial Nematic Liquid Crystals: Theory, Simulation, and Experiment; John Wiley \& Sons: Chichester, UK, 2015. 
17. Yu, L.J.; Saupe, A. Liquid crystalline phases of the sodium decylsulfate/decanol/water system. Nematic-nematic and cholesteric-cholesteric phase transitions. J. Am. Chem. Soc. 1980, 102, 4879. [CrossRef]

18. Bruckner, J.R.; Porada, J.H.; Dietrich, C.F.; Dierking, I.; Giesselmann, F. A Lyotropic Chiral Smectic C Liquid Crystal with Polar Electrooptic Switching. Angew. Chem. Int. Ed. 2013, 52, 8934-8937. [CrossRef]

19. Mukherjee, P.K.; Sen, K. On a new topology in the phase diagram of biaxial nematic liquid crystals. J. Chem. Phys. 2009, 130, 141101. [CrossRef]

20. Quist, P.-O. First order transitions to a lyotropic biaxial nematic. Liq. Cryst. 1995, 18, 623-629. [CrossRef]

21. Akpinar, E.; Otluoglu, K.; Turkmen, M.; Canioz, C.; Reis, D.; Neto, A.M.F. Effect of the presence of strong and weak electrolytes on the existence of uniaxial and biaxial nematic phases in lyotropic mixtures. Liq. Cryst. 2016, 43, 1693-1708. [CrossRef]

22. Diesselhorst, H.; Freundlich, H. On the double refraction of vanadine pentoxydsol. Phys. Z. 1915, 16, 419-425.

23. Freundlich, H. Die Doppelbrechung des Vanadinpentoxydsols. Ber. Bunsenges. Phys. Chem. 1916, 22, 27-33.

24. Zocher, H. Über freiwillige Strukturbildung in Solen. (Eine neue Art anisotrop flüssiger Medien.). Zeitschrift für Anorganische und Allgemeine Chemie 1925, 147, 91-110. [CrossRef]

25. Davidson, P.; Garreau, A.; Livage, J. Nematic colloidal suspensions of $\mathrm{V}_{2} \mathrm{O}_{5}$ in water-Or Zocher phases revisited. Liq. Cryst. 1994, 16, 905-910. [CrossRef]

26. Pelletier, O.; Sotta, P.; Davidson, P. Deuterium Nuclear Magnetic Resonance Study of the Nematic Phase of Vanadium Pentoxide Aqueous Suspensions. J. Phys. Chem. B 1999, 103, 5427-5433. [CrossRef]

27. Zocher, H.; Török, C. Neuere Beiträge zur Kenntnis der Taktosole. Colloid Polym. Sci. 1960, 173, 1-7.

28. Davidson, P.; Gabriel, J.-C.P.; Levelut, A.M.; Batail, P. A new nematic suspension based on all-inorganic polymer rods. Europhys. Lett. 1993, 21, 317-322. [CrossRef]

29. Zocher, H.; Török, C. Crystals of higher order and their relation to other superphases. Acta Crystallogr. 1967, 22, 751-755. [CrossRef]

30. Sonin, A.S. Inorganic lyotropic liquid crystals. J. Mater. Chem. 1998, 8, 2557-2574. [CrossRef]

31. Mourchid, A.; Delville, A.; Lambard, J.; Lécolier, E.; Levitz, P. Phase diagram of colloidal dispersions of anisotropic charged particles: Equilibrium properties, structure, and rheology of laponite suspensions. Langmuir 1995, 11, 1942-1950. [CrossRef]

32. Paineau, E.; Antonova, K.; Baravian, C.; Bihannic, I.; Davidson, P.; Dozov, I.; Impéror-Clerc, M.; Levitz, P.; Madsen, A.; Meneau, F.; et al. Liquid-Crystalline Nematic Phase in Aqueous Suspensions of a Disk-Shaped Natural Beidellite Clay. J. Phys. Chem. B 2009, 113, 15858-15869. [CrossRef]

33. Langmuir, I. The Role of Attractive and Repulsive Forces in the Formation of Tactoids, Thixotropic Gels, Protein Crystals and Coacervates. J. Chem. Phys. 1938, 6, 873. [CrossRef]

34. Gabriel, J.-C.P.; Sanchez, C.; Davidson, P. Observation of Nematic Liquid-Crystal Textures in Aqueous Gels of Smectite Clays. J. Phys. Chem. 1996, 100, 11139-11143. [CrossRef]

35. Kajiwara, K.; Donkai, N.; Hiragi, Y.; Inagaki, H. Lyotropic mesophase of imogolite, 1. Effect of polydispersity on phase diagram. Makromol. Chem. 1986, 187, 2883-2893. [CrossRef]

36. Kajiwara, K.; Donkai, N.; Fujiyoshi, Y.; Inagaki, H. Lyotropic mesophase of imogolite, 2. Microscopic observation of imogolite mesophase. Makromol. Chem. 1986, 187, 2895-2907. [CrossRef]

37. Dierking, I.; Al-Zangana, S. Lyotropic Liquid Crystal Phases from Anisotropic Nanomaterials. Nanomaterials 2017, 7, 305. [CrossRef]

38. Michot, L.J.; Bihannic, I.; Maddi, S.; Baravian, C.; Levitz, P.; Davidson, P. Sol/Gel and Isotropic/Nematic Transitions in Aqueous Suspensions of Natural Nontronite Clay. Influence of Particle Anisotropy. 1. Features of the I/N Transition. Langmuir 2008, 24, 3127-3139. [CrossRef]

39. Onsager, L. The effects of shape on the interaction of colloidal particles. Ann. N. Y. Acad. Sci. 1949, 51, 627-659. [CrossRef]

40. Barry, E.; Beller, D.; Dogic, Z. A model liquid crystalline system based on rodlike viruses with variable chirality and persistence length. Soft Matter 2009, 5, 2563-2570. [CrossRef]

41. Mayer, A. Über die Mosaikkrankheit des Tabaks. Die Landwirtsch. Versuchsstationen. 1886, 32, 451-467.

42. Iwanowski, D. Über die Mosaikkrankheit der Tabakspflanze. Bulletin Scientifique Publié Par l'Académie Impériale des Sciences de Saint-Pétersbourg/Nouvelle Serie III 1892, 35, 67-70.

43. Beijerinck, M.W. Über ein Contagium vivum fluidum als Ursache der Fleckenkrankheit der Tabaksblätter. In Verhandelingen der Koninklijke Akademie van Wetenschappen Te Amsterdam; J. Müller: Brake, Germany, 1898; Volume 65, pp. 1-22. 
44. Kausche, G.A.; Pfankuch, E.; Ruska, H. The visualisation of herbal viruses in surface microscopes. Naturwissenschaften 1939, 27, 292-299. [CrossRef]

45. Bawden, F.C.; Pirie, N.W.; Bernal, J.D.; Fankuchen, I. Liquid Crystalline Substances from Virus-infected Plants. Nature 1936, 138, 1051-1052. [CrossRef]

46. Oldenbourg, R.; Wen, X.; Meyer, R.B.; Caspar, D.L.D. Orientational Distribution Function in Nematic Tobacco-Mosaic-Virus Liquid Crystals Measured by X-Ray Diffraction. Phys. Rev. Lett. 1988, 61, 1851-1854. [CrossRef]

47. Fraden, S.; Maret, G.; Caspar, D.L.D. Angular correlations and the isotropic-nematic phase transition in suspensions of tobacco mosaic virus. Phys. Rev. E 1993, 48, 2816-2837. [CrossRef] [PubMed]

48. Graf, H.; Löwen, H. Phase diagram of tobacco mosaic virus solutions. Phys. Rev. E 1999, 59, $1932-1942$. [CrossRef]

49. Dogic, Z.; Fraden, S. Cholesteric Phase in Virus Suspensions. Langmuir 2000, 16, 7820-7824. [CrossRef]

50. Dogic, Z.; Fraden, S. Smectic Phase in a Colloidal Suspension of Semiflexible Virus Particles. Phys. Rev. Lett. 1997, 78, 2417-2420. [CrossRef]

51. Dogic, Z.; Fraden, S. Ordered phases of filamentous viruses. Curr. Opin. Colloid Interface Sci. 2006, 11, 47-55. [CrossRef]

52. Dogic, Z. Filamentous Phages as a Model System in Soft Matter Physics. Front. Microbiol. 2016, 7, 349. [CrossRef]

53. Adams, M.; Dogic, Z.; Keller, S.L.; Fraden, S. Entropically driven microphase transitions in mixtures of colloidal rods and spheres. Nature 1998, 393, 349-352. [CrossRef]

54. Leforestier, A.; Livolant, F. The Bacteriophage Genome Undergoes a Succession of Intracapsid Phase Transitions upon DNA Ejection. J. Mol. Boil. 2010, 396, 384-395. [CrossRef] [PubMed]

55. Leforestier, A.; Livolant, F. Supramolecular ordering of DNA in the cholesteric liquid crystalline phase: An ultrastructural study. Biophys. J. 1993, 65, 56-72. [CrossRef]

56. Strzelecka, T.E.; Davidson, M.W.; Rill, R.L. Multiple liquid crystal phases of DNA at high concentrations. Nature 1988, 331, 457-460. [CrossRef] [PubMed]

57. Zanchetta, G.; Nakata, M.; Buscaglia, M.; Clark, N.A.; Bellini, T. Liquid crystal ordering of DNA and RNA oligomers with partially overlapping sequences. J. Phys. Condens. Matter 2008, 20, 494214. [CrossRef]

58. Smalyukh, I.I.; Zribi, O.V.; Butler, J.C.; Lavrentovich, O.D.; Wong, G.C.L. Structure and Dynamics of Liquid Crystalline Pattern Formation in Drying Droplets of DNA. Phys. Rev. Lett. 2006, 96, 177801. [CrossRef]

59. Salamonczyk, M.; Zhang, J.; Portale, G.; Zhu, C.; Kentzinger, E.; Gleeson, J.T.; Jakli, A.; De Michele, C.; Dhont, J.K.G.; Sprunt, S.; et al. Smectic phase in suspensions of gapped DNA duplexes. Nat. Commun. 2016, 7, 13358. [CrossRef]

60. Storm, I.M.; Kornreich, M.; Hernandez-Garcia, A.; Voets, I.K.; Beck, R.; Stuart, M.A.C.; Leermakers, F.A.M.; De Vries, R. Liquid Crystals of Self-Assembled DNA Bottlebrushes. J. Phys. Chem. B 2015, 119, 4084-4092. [CrossRef]

61. Brach, K.; Hatakeyama, A.; Nogues, C.; Olesiak-Banska, J.; Buckle, M.; Matczyszyn, K. Photochemical analysis of structural transitions in DNA liquid crystals reveals differences in spatial structure of DNA molecules organized in liquid crystalline form. Sci. Rep. 2018, 8, 4528. [CrossRef]

62. George, J.; Sabapathi, S. Cellulose nanocrystals: Synthesis, functional properties, and applications. Nanotechnol. Sci. Appl. 2015, 8, 45-54. [CrossRef]

63. Pääkkö, M.; Ankerfors, M.; Kosonen, H.; Nykänen, A.; Ahola, S.; Österberg, M.; Ruokolainen, J.; Laine, J.; Larsson, P.T.; Ikkala, O.; et al. Enzymatic Hydrolysis Combined with Mechanical Shearing and High-Pressure Homogenization for Nanoscale Cellulose Fibrils and Strong Gels. Biomacromolecules 2007, 8, 1934-1941. [CrossRef]

64. Kloser, E.; Gray, D.G. Surface Grafting of Cellulose Nanocrystals with Poly(ethylene oxide) in Aqueous Media. Langmuir 2010, 26, 13450-13456. [CrossRef] [PubMed]

65. Gray, D.G.; Mu, X. Chiral Nematic Structure of Cellulose Nanocrystal Suspensions and Films; Polarized Light and Atomic Force Microscopy. Materials 2015, 8, 7873-7888. [CrossRef] [PubMed]

66. Gray, D.G. Recent Advances in Chiral Nematic Structure and Iridescent Color of Cellulose Nanocrystal Films. Nanomaterials 2016, 6, 213. [CrossRef] [PubMed] 
67. Lagerwall, J.P.F.; Schütz, C.; Salajkova, M.; Noh, J.; Park, J.H.; Scalia, G.; Bergström, L. Cellulose nanocrystal-based materials: From liquid crystal self-assembly and glass formation to multifunctional thin films. NPG Asia Mater. 2014, 6, e80. [CrossRef]

68. Azzam, F.; Heux, L.; Jean, B. Adjustment of the Chiral Nematic Phase Properties of Cellulose Nanocrystals by Polymer Grafting. Langmuir 2016, 32, 4305-4312. [CrossRef] [PubMed]

69. Abitbol, T.; Kam, D.; Levi-Kalisman, Y.; Gray, D.G.; Shoseyov, O. Surface Charge Influence on the Phase Separation and Viscosity of Cellulose Nanocrystals. Langmuir 2018, 34, 3925-3933. [CrossRef]

70. Spontak, R.J.; El-Nokaly, M.A.; Bartolo, R.G.; Burns, J.L. Polymer Solutions, Blends and Interfaces; Noda, I., Rubingh, D.N., Eds.; Elsevier Science Publishers B.V.: Amsterdam, The Netherlands, 1992.

71. Cowie, J.; Arrighi, V.; Cameron, J.; McEwan, I.; McEwen, I.J. Lyotropic liquid crystalline cellulose derivatives in blends and molecular composites. Polymer 2001, 42, 9657-9663. [CrossRef]

72. Cowie, J.; Arrighi, V.; Cameron, J.; Robson, D. Lyotropic liquid crystalline cellulose derivatives in blends and molecular composites. Macromol. Symp. 2000, 152, 107-116. [CrossRef]

73. Kamide, K.; Okajima, K.; Matsui, T.; Kajita, S. Formation of Lyotropic Liquid Crystals of Cellulose Derivatives Dissolved in Inorganic Acids. Polym. J. 1986, 18, 273-276. [CrossRef]

74. Onofrei, M.-D.; Dobos, A.M.; Stoica, I.; Olaru, N.; Olaru, L.; Ioan, S. Lyotropic Liquid Crystal Phases in Cellulose Acetate Phthalate/Hydroxypropyl Cellulose Blends. J. Polym. Environ. 2013, 22, 99-111. [CrossRef]

75. Dierking, I.; Scalia, G.; Morales, P.; LeClere, D. Aligning and Reorienting Carbon Nanotubes with Nematic Liquid Crystals. Adv. Mater. 2004, 16, 865-869. [CrossRef]

76. Dierking, I.; Scalia, G.; Morales, P. Liquid crystal-carbon nanotube dispersions. J. Appl. Phys. 2005, $97,44309$. [CrossRef]

77. Lynch, M.D.; Patrick, D.L. Organizing Carbon Nanotubes with Liquid Crystals. Nano Lett. 2002, 2, 1197-1201. [CrossRef]

78. Lagerwall, J.P.F.; Scalia, G. Carbon nanotubes in liquid crystals. J. Mater. Chem. 2008, 18, 2890. [CrossRef]

79. Yakemseva, M.; Dierking, I.; Kapernaum, N.; Usol'Tseva, N.V.; Giesselmann, F. Dispersions of multi-wall carbon nanotubes in ferroelectric liquid crystals. Eur. Phys. J. E 2014, 37, 7. [CrossRef] [PubMed]

80. Lagerwall, J.P.F.; Scalia, G.; Haluska, M.; Dettlaff-Weglikowska, U.; Giesselmann, F.; Roth, S. Simultaneous alignment and dispersion of carbon nanotubes with lyotropic liquid crystals. Phys. Status Solidi B 2006, 243, 3046-3049. [CrossRef]

81. Lagerwall, J.P.F.; Scalia, G.; Haluska, M.; Dettlaff-Weglikowska, U.; Roth, S.; Giesselmann, F. Nanotube Alignment Using Lyotropic Liquid Crystals. Adv. Mater. 2007, 19, 359-364. [CrossRef]

82. Jiang, W.; Yu, B.; Liu, W.; Hao, J. Carbon Nanotubes Incorporated within Lyotropic Hexagonal Liquid Crystal Formed in Room-Temperature Ionic Liquids. Langmuir 2007, 23, 8549-8553. [CrossRef]

83. Scalia, G.; Von Bühler, C.; Hägele, C.; Roth, S.; Giesselmann, F.; Lagerwall, J.P.F. Spontaneous macroscopic carbon nanotube alignment via colloidal suspension in hexagonal columnar lyotropic liquid crystals. Soft Matter 2008, 4, 570-576. [CrossRef]

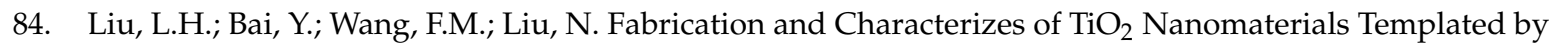
Lyotropic Liquid Crystal. Adv. Mater. Res. 2011, 399, 532-537. [CrossRef]

85. Saliba, S.; Davidson, P.; Impéror-Clerc, M.; Mingotaud, C.; Kahn, M.L.; Marty, J.-D. Facile direct synthesis of $\mathrm{ZnO}$ nanoparticles within lyotropic liquid crystals: Towards organized hybrid materials. J. Mater. Chem. 2011, 21, 18191. [CrossRef]

86. Somoza, A.M.; Sagui, C.; Roland, C. Liquid-crystal phases of capped carbon nanotubes. Phys. Rev. B 2001, 63, 81403. [CrossRef]

87. Song, W.; Kinloch, I.A.; Windle, A.H. Nematic Liquid Crystallinity of Multiwall Carbon Nanotubes. Science 2003, 302, 1363. [CrossRef] [PubMed]

88. Song, W.; Windle, A.H. Isotropic-Nematic Phase Transition of Dispersions of Multiwall Carbon Nanotubes. Macromolecules 2005, 38, 6181-6188. [CrossRef]

89. Badaire, S.; Zakri, C.; Maugey, M.; Derré, A.; Barisci, J.N.; Wallace, G.G.; Poulin, P. Liquid Crystals of DNA-Stabilized Carbon Nanotubes. Adv. Mater. 2005, 17, 1673-1676. [CrossRef]

90. Puech, N.; Blanc, C.; Grelet, E.; Zamora-Ledezma, C.; Maugey, M.; Zakri, C.; Anglaret, E.; Poulin, P. Highly Ordered Carbon Nanotube Nematic Liquid Crystals. J. Phys. Chem. C 2011, 115, 3272-3278. [CrossRef] 
91. Davis, V.A.; Ericson, L.M.; Parra-Vasquez, A.N.G.; Fan, H.; Wang, Y.; Prieto, V.; Longoria, J.A.; Ramesh, S.; Saini, R.K.; Kittrell, C.; et al. Phase behaviour and rheology of SWNTs in superacids. Macromolecules 2004, 37, 154-160. [CrossRef]

92. Rai, P.K.; Pinnick, R.A.; Parra-Vasquez, A.N.G.; Davis, V.A.; Schmidt, H.K.; Hauge, R.H.; Smalley, R.E.; Pasquali, M. Isotropic-Nematic Phase Transition of Single-Walled Carbon Nanotubes in Strong Acids. J. Am. Chem. Soc. 2006, 128, 591-595. [CrossRef]

93. Zhang, S.; Majewski, P.W.; Keskar, G.; Pfefferle, L.D.; Osuji, C.O. Lyotropic Self-Assembly of High-Aspect-Ratio Semiconductor Nanowires of Single-Crystal ZnO. Langmuir 2011, 27, 11616-11621. [CrossRef]

94. Zhang, S.; Pelligra, C.I.; Keskar, G.; Majewski, P.W.; Ren, F.; Pfefferle, L.D.; Osuji, C.O. Liquid Crystalline Order and Magnetocrystalline Anisotropy in Magnetically Doped Semiconducting ZnO Nanowires. ACS Nano 2011, 5, 8357-8364. [CrossRef]

95. Ren, Z.; Chen, C.; Hu, R.; Mai, K.; Qian, G.; Wang, Z. Two-Step Self-Assembly and Lyotropic Liquid Crystal Behavior of TiO2 Nanorods. J. Nanomater. 2012, 2012, 180989. [CrossRef]

96. Li, L.-S.; Walda, J.; Manna, L.; Alivisatos, A.P.; Alivisatos, A.P. Semiconductor Nanorod Liquid Crystals. Nano Lett. 2002, 2, 557-560. [CrossRef]

97. Li, L.-S.; Alivisatos, A.P. Semiconductor Nanorod Liquid Crystals and Their Assembly on a Substrate. Adv. Mater. 2003, 15, 408-411. [CrossRef]

98. Behabtu, N.; Lomeda, J.R.; Green, M.J.; Higginbotham, A.L.; Sinitskii, A.; Kosynkin, D.V.; Tsentalovich, D.; Parra-Vasquez, A.N.G.; Schmidt, J.; Kesselman, E.; et al. Spontaneous high-concentration dispersions and liquid crystals of graphene. Nat. Nanotechnol. 2010, 5, 406-411. [CrossRef] [PubMed]

99. Xu, Z.; Gao, C. Graphene chiral liquid crystals and macroscopic assembled fibres. Nat. Commun. 2011, 2, 571. [CrossRef]

100. Kim, J.E.; Han, T.H.; Lee, S.H.; Kim, J.Y.; Ahn, C.W.; Yun, J.M.; Kim, S.O.; Lee, J. Graphene Oxide Liquid Crystals. Angew. Chem. Int. Ed. 2011, 50, 3043-3047. [CrossRef]

101. Al-Zangana, S.; Iliut, M.; Turner, M.; Vijayaraghavan, A.; Dierking, I. Confinement effects on lyotropic nematic liquid crystal phases of graphene oxide dispersions. 2D Mater. 2017, 4, 041004. [CrossRef]

102. Dan, B.; Behabtu, N.; Martinez, A.; Evans, J.S.; Kosynkin, D.V.; Tour, J.M.; Pasquali, M.; Smalyukh, I.I. Liquid crystals of aqueous, giant graphene oxide flakes. Soft Matter 2011, 7, 11154. [CrossRef]

103. Jalili, R.; Aboutalebi, S.H.; Esrafilzadeh, D.; Shepherd, R.L.; Chen, J.; Aminorroaya-Yamini, S.; Konstantinov, K.; Minett, A.I.; Razal, J.M.; Wallace, G.G. Scalable One-Step Wet-Spinning of Graphene Fibers and Yarns from Liquid Crystalline Dispersions of Graphene Oxide: Towards Multifunctional Textiles. Adv. Funct. Mater. 2013, 23, 5345-5354. [CrossRef]

104. Kim, J.Y.; Kim, S.O. Liquid crystals: Electric fields line up graphene oxide. Nat. Mater. 2014, 13, $325-326$. [CrossRef]

105. Hong, S.-H.; Shen, T.-Z.; Song, J.-K. Electro-optical Characteristics of Aqueous Graphene Oxide Dispersion Depending on Ion Concentration. J. Phys. Chem. C 2014, 118, 26304-26312. [CrossRef]

106. Shen, T.-Z.; Hong, S.-H.; Song, J.-K. Electro-optical switching of graphene oxide liquid crystals with an extremely large Kerr coefficient. Nat. Mater. 2014, 13, 394-399. [CrossRef] [PubMed]

107. Ahmad, R.T.M.; Hong, S.-H.; Shen, T.-Z.; Song, J.-K. Optimization of particle size for high birefringence and fast switching time in electro-optical switching of graphene oxide dispersions. Opt. Express 2015, 23, 4435-4440. [CrossRef] [PubMed]

108. Narayan, R.; Kim, J.E.; Kim, J.Y.; Lee, K.-E.; Kim, S.O. Graphene Oxide Liquid Crystals: Discovery, Evolution and Applications. Adv. Mater. 2016, 28, 3045-3068. [CrossRef]

109. Sasikala, S.P.; Lim, J.; Kim, I.H.; Jung, H.J.; Yun, T.; Han, T.H.; Kim, S.O. Graphene oxide liquid crystals: A frontier 2D soft material for graphene-based functional materials. Chem. Soc. Rev. 2018, 47, 6013-6045. [CrossRef] [PubMed]

110. Draude, A.; Dierking, I. Lyotropic Liquid Crystals from Colloidal Suspensions of Graphene Oxide. Crystals 2019, 9, 455. [CrossRef]

111. Al-Zangana, S.; Iliut, M.; Turner, M.; Vijayaraghavan, A.; Dierking, I. Properties of a Thermotropic Nematic Liquid Crystal Doped with Graphene Oxide. Adv. Opt. Mater. 2016, 4, 1541-1548. [CrossRef]

112. Al-Zangana, S.; Iliut, M.; Boran, G.; Turner, M.; Vijayaraghavan, A.; Dierking, I. Dielectric spectroscopy of isotropic liquids and liquid crystal phases with dispersed graphene oxide. Sci. Rep. 2016, 6, 31885. [CrossRef] 
113. Zamora-Ledezma, C.; Puech, N.; Zakri, C.; Grelet, E.; Moulton, S.E.; Wallace, G.G.; Gambhir, S.; Blanc, C.; Anglaret, E.; Poulin, P. Liquid Crystallinity and Dimensions of Surfactant-Stabilized Sheets of Reduced Graphene Oxide. J. Phys. Chem. Lett. 2012, 3, 2425-2430. [CrossRef]

114. Kim, M.J.; Park, J.H.; Yamamoto, J.; Kim, Y.S.; Scalia, G. Electro-optic switching with liquid crystal graphene. Phys. Status Solidi Rapid Res. Lett. 2016, 10, 397-403. [CrossRef]

115. Jalili, R.; Aminorroaya-Yamini, S.; Benedetti, T.R.B.; Aboutalebi, S.H.; Chao, Y.; Wallace, G.G.; Officer, D.L. Processable 2D materials beyond graphene: $\mathrm{MoS}_{2}$ liquid crystals and fibres. Nanoscale 2016, 8, 16862-16867. [CrossRef] [PubMed]

116. Xia, Y.; Mathis, T.S.; Zhao, M.-Q.; Anasori, B.; Dang, A.; Zhou, Z.; Cho, H.; Gogotsi, Y.; Yang, S. Thicknessindependent capacitance of vertically aligned liquid-crystalline MXenes. Nature 2018, 557, 409-412. [CrossRef] [PubMed]

117. Nicolosi, V.; Chhowalla, M.; Kanatzidis, M.G.; Strano, M.S.; Coleman, J.N. Liquid Exfoliation of Layered Materials. Science 2013, 340, 1226419. [CrossRef]

118. Liu, Y.; Xu, Z.; Gao, W.; Cheng, Z.; Gao, C. Graphene and Other 2D Colloids: Liquid Crystals and Macroscopic Fibers. Adv. Mater. 2017, 29, 1606794. [CrossRef]

119. Xin, G.; Yao, T.; Sun, H.; Scott, S.M.; Shao, D.; Wang, G.; Lian, J. Highly thermally conductive and mechanically strong graphene fibers. Science 2015, 349, 1083-1087. [CrossRef]

120. Li, P.; Wong, M.; Zhang, X.; Yao, H.; Ishige, R.; Takahara, A.; Miyamoto, M.; Nishimura, R.; Sue, H. Tunable Lyotropic Photonic Liquid Crystal Based on Graphene Oxide. ACS Photon. 2014, 1, 79-86. [CrossRef]

121. Akbari, A.; Sheath, P.; Martin, S.T.; Shinde, D.B.; Shaibani, M.; Banerjee, P.C.; Tkacz, R.; Bhattacharyya, D.; Majumder, M. Large-area graphene-based nanofiltration membranes by shear alignment of discotic nematic liquid crystals of graphene oxide. Nat. Commun. 2016, 7, 10891. [CrossRef]

122. He, L.; Ye, J.; Shuai, M.; Zhu, Z.; Zhou, X.; Wang, Y.; Li, Y.; Su, Z.; Zhang, H.; Chen, Y.; et al. Graphene oxide liquid crystals for reflective displays without polarizing optics. Nanoscale 2015, 7, 1616-1622. [CrossRef]

123. Lydon, J.E. Chromonics. In Handbook of Liquid Crystals, Vol 2B; Demus, D., Goodby, J., Gray, G.W., Speiss, H.-W., Vi, V., II, Eds.; Wiley-VCH: Weinheim, Germany, 1998; pp. 981-1007.

124. Lydon, J.E. Chromonic liquid crystal phases. Curr. Opin. Colloid Interface Sci. 1998, 3, 458-466. [CrossRef]

125. Tam-Chang, S.-W.; Huang, L. Chromonic liquid crystals: Properties and applications as functional materials. Chem. Commun. 2008, 17, 1957. [CrossRef]

126. Nastishin, Y.A.; Liu, H.; Shiyanovskii, S.V.; Lavrentovich, O.; Kostko, A.; Anisimov, M.A. Pretransitional fluctuations in the isotropic phase of a lyotropic chromonic liquid crystal. Phys. Rev. E 2004, 70, 051706. [CrossRef] [PubMed]

127. Hartshorne, N.H.; Woodard, G.D. Mesomorphism in the System Disodium Chromoglycate-Water. Mol. Cryst. Liq. Cryst. 1973, 23, 343-368. [CrossRef]

128. Kustanovich, I.; Poupko, R.; Zimmermann, H.; Luz, Z.; Labes, M.M. Lyomesophases of the diethylammonium flufenamate-water system studied by deuterium NMR spectroscopy. J. Am. Chem. Soc. 1985, 107, 3494-3501. [CrossRef]

129. Horowitz, V.R.; Janowitz, L.A.; Modic, A.L.; Heiney, P.A.; Collings, P.J. Aggregation behavior and chromonic liquid crystal properties of an anionic monoazo dye. Phys. Rev. E 2005, 72, 041710. [CrossRef]

130. Kostko, A.; Cipriano, B.H.; Pinchuk, O.A.; Ziserman, L.; Anisimov, M.A.; Danino, D.; Raghavan, S.R. Salt Effects on the Phase Behavior, Structure, and Rheology of Chromonic Liquid Crystals. J. Phys. Chem. B 2005, 109, 19126-19133. [CrossRef] [PubMed]

131. Sidky, H.; Whitmer, J.K. The Emergent Nematic Phase in Ionic Chromonic Liquid Crystals. J. Phys. Chem. B 2017, 121, 6691-6698. [CrossRef]

132. Romani, E.; Ferrarini, A.; De Michele, C. Elastic Constants of Chromonic Liquid Crystals. Macromolecules 2018, 51, 5409-5419. [CrossRef]

133. Jeong, J.; Davidson, Z.S.; Collings, P.J.; Lubensky, T.C.; Yodh, A.G. Chiral symmetry breaking and surface faceting in chromonic liquid crystal droplets with giant elastic anisotropy. Proc. Natl. Acad. Sci. USA 2014, 111, 1742-1747. [CrossRef] [PubMed]

134. Zhou, S.; Shiyanovskii, S.V.; Park, H.-S.; Lavrentovich, O.D. Fine structure of the topological defect cores studied for disclinations in lyotropic chromonic liquid crystals. Nat. Commun. 2017, 8, 14974. [CrossRef]

135. Akpinar, E.; Topcu, G.; Reis, D.; Neto, A.M.F. Effect of the presence of the anionic azo dye Sunset Yellow in lyotropic mixtures with uniaxial and biaxial nematic phases. Submitted. 
136. Valášek, J. Piezo-Electric and Allied Phenomena in Rochelle Salt. Phys. Rev. 1921, 17, 475-481. [CrossRef]

137. Meyer, R.; Liebert, L.; Strzelecki, L.; Keller, P. Ferroelectric liquid crystals. J. Phys. Lett. 1975, 36, 69-71. [CrossRef]

138. Clark, N.A.; Lagerwall, S.T. Submicrosecond bistable electro-optic switching in liquid crystals. Appl. Phys. Lett. 1980, 36, 899-901. [CrossRef]

139. Schafheutle, M.A.; Finkelmann, H. Shapes of Micelles and Molecular Geometry Synthesis and Studies on the Phase Behaviour, Surface Tension and Rheology of Rigid Rod-Like Surfactants in Aqueous Solutions. Liq. Cryst. 1988, 3, 1369-1386. [CrossRef]

140. Ujiie, S.; Yano, Y. Thermotropic and lyotropic behavior of novel amphiphilic liquid crystals having hydrophilic poly(ethyleneimine) units. Chem. Commun. 2000, 1, 79-80. [CrossRef]

141. Harjung, M.D.; Giesselmann, F. Electroclinic effect in the chiral lamellar $\alpha$ phase of a lyotropic liquid crystal. Phys. Rev. E 2018, 97, 032705. [CrossRef] [PubMed]

142. Harjung, M.D.; Schubert, C.P.J.; Knecht, F.; Porada, J.H.; Lemieux, R.P.; Giesselmann, F. New amphiphilic materials showing the lyotropic analogue to the thermotropic smectic $C^{*}$ liquid crystal phase. J. Mater. Chem. C 2017, 5, 7452-7457. [CrossRef]

143. Bruckner, J.R.; Giesselmann, F. The Lyotropic Analog of the Polar SmC* Phase. Crystals 2019, 9, 568. [CrossRef]

144. Menzel, A.M. Tuned, driven, and active soft matter. Phys. Rep. 2015, 554, 1-45. [CrossRef]

145. Golestanian, R.; Ramaswamy, S. Active Matter. Eur. Phys. J. E 2013, 36, 54002. [CrossRef] [PubMed]

146. Bukusoglu, E.; Pantoja, M.B.; Mushenheim, P.C.; Wang, X.; Abbott, N.L. Design of Responsive and Active (Soft) Materials Using Liquid Crystals. Annu. Rev. Chem. Biomol. Eng. 2016, 7, 163-196. [CrossRef]

147. Doostmohammadi, A.; Ignés-Mullol, J.; Yeomans, J.M.; Sagués, F. Active nematics. Nat. Commun. 2018, 9 , 3246. [CrossRef] [PubMed]

148. Dombrowski, C.; Cisneros, L.; Chatkaew, S.; E Goldstein, R.; Kessler, J.O. Self-Concentration and Large-Scale Coherence in Bacterial Dynamics. Phys. Rev. Lett. 2004, 93, 098103. [CrossRef] [PubMed]

149. Li, H.; Shi, X.-Q.; Huang, M.; Chen, X.; Xiao, M.; Liu, C.; Chaté, H.; Zhang, H.P. Data-driven quantitative modeling of bacterial active nematics. Proc. Natl. Acad. Sci. USA 2018, 116, 777-785. [CrossRef] [PubMed]

150. Sanchez, T.; Chen, D.T.N.; DeCamp, S.J.; Heymann, M.; Dogic, Z. Spontaneous motion in hierarchically assembled active matter. Nature 2012, 491, 431-434. [CrossRef] [PubMed]

151. Henkin, G.; DeCamp, S.J.; Chen, D.T.N.; Sanchez, T.; Dogic, Z. Tunable dynamics of microtubule-based active isotropic gels. Philos. Trans. R. Soc. A Math. Phys. Eng. Sci. 2014, 372, 20140142. [CrossRef] [PubMed]

152. Schaller, V.; Weber, C.; Semmrich, C.; Frey, E.; Bausch, A.R. Polar patterns of driven filaments. Nature 2010, 467, 73-77. [CrossRef]

153. Zhang, R.; Kumar, N.; Ross, J.L.; Gardel, M.L.; De Pablo, J.J. Interplay of structure, elasticity, and dynamics in actin-based nematic materials. Proc. Natl. Acad. Sci. 2017, 115, E124-E133. [CrossRef]

154. Kumar, N.; Zhang, R.; De Pablo, J.J.; Gardel, M.L. Tunable structure and dynamics of active liquid crystals. Sci. Adv. 2018, 4, eaat7779. [CrossRef]

155. Zhou, S.; Sokolov, A.; Lavrentovich, O.D.; Aranson, I.S. Living Liquid Crystals. Biophys. J. 2014, 106, 420a. [CrossRef]

156. Peng, C.; Turiv, T.; Guo, Y.; Wei, Q.-H.; Lavrentovich, O.D. Command of active matter by topological defects and patterns. Science 2016, 354, 882-885. [CrossRef] [PubMed]

157. Genkin, M.M.; Sokolov, A.; Lavrentovich, O.D.; Aranson, I.S. Topological Defects in a Living Nematic Ensnare Swimming Bacteria. Phys. Rev. X 2017, 7, 011029. [CrossRef]

158. Genkin, M.M.; Sokolov, A.; Aranson, I.S. Spontaneous topological charging of tactoids in a living nematic. New J. Phys. 2018, 20, 043027. [CrossRef]

159. Woolverton, C.J.; Gustely, E.; Li, L.; Lavrentovich, O.D. Liquid crystal effects on bacterial viability. Liq. Cryst. 2005, 32, 417-423. [CrossRef]

160. Mezzenga, R.; Seddon, J.M.; Drummond, C.J.; Boyd, B.J.; Schröder-Turk, G.E.; Sagalowicz, L. Nature-Inspired Design and Application of Lipidic Lyotropic Liquid Crystals. Adv. Mater. 2019, 31, e1900818. [CrossRef]

161. Sadeghpour, A. Lyotropic Liquid Crystalline Phases for the Formulation of Future Functional Foods. J. Nutr. Health Food Eng. 2016, 5, 553-557. [CrossRef] 
162. Garti, N.; Libster, D.; Aserin, A. Lipid polymorphism in lyotropic liquid crystals for triggered release of bioactives. Food Funct. 2012, 3, 700-713. [CrossRef]

163. Larsson, K. Lyotropic liquid crystals and their dispersions relevant in foods. Curr. Opin. Colloid Interface Sci. 2009, 14, 16-20. [CrossRef]

164. Engels, T.; Von Rybinski, W. Liquid crystalline surfactant phases in chemical applications. J. Mater. Chem. 1998, 8, 1313-1320. [CrossRef]

165. Negrini, R.; Mezzenga, R. pH-Responsive Lyotropic Liquid Crystals for Controlled Drug Delivery. Langmuir 2011, 27, 5296-5303. [CrossRef]

166. Aleandri, S.; Speziale, C.; Mezzenga, R.; Landau, E.M. Design of Light-Triggered Lyotropic Liquid Crystal Mesophases and Their Application as Molecular Switches in “On Demand” Release. Langmuir 2015, 31, 6981-6987. [CrossRef]

167. Kim, N.-H.; Jahn, A.; Cho, S.-J.; Kim, J.S.; Ki, M.-H.; Kim, D.-D. Lyotropic liquid crystal systems in drug delivery: A review. J. Pharm. Investig. 2014, 45, 1-11. [CrossRef]

168. Guo, C.; Wang, J.; Cao, F.; Lee, R.J.; Zhai, G. Lyotropic liquid crystal systems in drug delivery. Drug Discov. Today 2010, 15, 1032-1040. [CrossRef]

169. Gupta, V.K. Optical Amplification of Ligand-Receptor Binding Using Liquid Crystals. Science 1998, 279, 2077-2080. [CrossRef]

170. Luan, C.; Luan, H.; Luo, D. Luan Application and Technique of Liquid Crystal-Based Biosensors. Micromachines 2020, 11, 176. [CrossRef] [PubMed]

171. Shiyanovskii, S.V.; Lavrentovich, O.D.; Schneider, T.; Ishikawa, T.; Smalyukh, I.I.; Woolverton, C.J.; Niehaus, G.D.; Doane, K.J. Lyotropic Chromonic Liquid Crystals for Biological Sensing Applications. Mol. Cryst. Liq. Cryst. 2005, 434, 259-270. [CrossRef]

172. Tan, H.; Yang, S.; Shen, G.; Yu, R.; Wu, Z. Signal-Enhanced Liquid-Crystal DNA Biosensors Based on Enzymatic Metal Deposition. Angew. Chem. Int. Ed. 2010, 49, 8608-8611. [CrossRef]

173. Popov, P.; Honaker, L.; Kooijman, E.E.; Mann, E.K.; Jákli, A. A liquid crystal biosensor for specific detection of antigens. Sens. Bio-Sens. Res. 2016, 8, 31-35. [CrossRef]

174. Oton, E.; Oton, J.M.; Caño-García, M.; Escolano, J.M.; Quintana, X.; Geday, M.A. Rapid detection of pathogens using lyotropic liquid crystals. Opt. Express 2019, 27, 10098-10107. [CrossRef]

175. De Souza, J.F.; Pontes, K.D.S.; Alves, T.F.; Amaral, V.; Rebelo, M.A.; Hausen, M.; Chaud, M.V. Spotlight on Biomimetic Systems Based on Lyotropic Liquid Crystal. Molecules 2017, 22, 419. [CrossRef]

176. Fowler, C.E.; Shenton, W.; Stubbs, G.; Mann, S. Tobacco Mosaic Virus Liquid Crystals as Templates for the Interior Design of Silica Mesophases and Nanoparticles. Adv. Mater. 2001, 13, 1266-1269. [CrossRef]

177. Dellinger, T.M.; Braun, P.V. Lyotropic Liquid Crystals as Nanoreactors for Nanoparticle Synthesis. Chem. Mater. 2004, 16, 2201-2207. [CrossRef]

178. Wang, C.; Chen, D.; Jiao, X. Lyotropic liquid crystal directed synthesis of nanostructured materials. Sci. Technol. Adv. Mater. 2009, 10, 23001. [CrossRef] [PubMed]

179. Umadevi, S.; Umamaheswari, R.; Ganesh, V. Lyotropic liquid crystal-assisted synthesis of micro- and nanoparticles of silver. Liq. Cryst. 2017, 44,1-12. [CrossRef]

180. Salili, S.M.; Worden, M.; Nemati, A.; Miller, D.W.; Hegmann, T. Synthesis of Distinct Iron Oxide Nanomaterial Shapes Using Lyotropic Liquid Crystal Solvents. Nanomaterials 2017, 7, 211. [CrossRef] [PubMed]

181. Hegmann, T.; Qi, H.; Marx, V.M. Nanoparticles in Liquid Crystals: Synthesis, Self-Assembly, Defect Formation and Potential Applications. J. Inorg. Organomet. Polym. Mater. 2007, 17, 483-508. [CrossRef]

182. Kuijk, A.; Van Blaaderen, A.; Imhof, A. Synthesis of Monodisperse, Rodlike Silica Colloids with Tunable Aspect Ratio. J. Am. Chem. Soc. 2011, 133, 2346-2349. [CrossRef] [PubMed]

183. Park, J.H.; Noh, J.; Schütz, C.; Salazar-Alvarez, G.; Scalia, G.; Bergström, L.; Lagerwall, J.P.F. Macroscopic Control of Helix Orientation in Films Dried from Cholesteric Liquid-Crystalline Cellulose Nanocrystal Suspensions. ChemPhysChem 2014, 15, 1477-1484. [CrossRef]

184. Querejeta-Fernández, A.; Chauve, G.; Méthot, M.; Bouchard, J.; Kumacheva, E. Chiral Plasmonic Films Formed by Gold Nanorods and Cellulose Nanocrystals. J. Am. Chem. Soc. 2014, 136, 4788-4793. [CrossRef] 
185. Liu, Q.; Campbell, M.G.; Evans, J.S.; Smalyukh, I.I. Orientationally Ordered Colloidal Co-Dispersions of Gold Nanorods and Cellulose Nanocrystals. Adv. Mater. 2014, 26, 7178-7184. [CrossRef]

186. Chu, G.; Wang, X.; Chen, T.; Gao, J.; Gai, F.; Wang, Y.; Xu, Y. Optically Tunable Chiral Plasmonic Guest-Host Cellulose Films Weaved with Long-range Ordered Silver Nanowires. ACS Appl. Mater. Interfaces 2015, 7, 11863-11870. [CrossRef] [PubMed] 